\title{
Seminal plasma effects on sperm handling and female fertility
}

\author{
WMC Maxwell, SP de Graaf, R El-Hajj Ghaoui and G Evans \\ Faculty of Veterinary Science, University of Sydney, NSW 2006, Australia
}

\begin{abstract}
The components of ruminant seminal plasma and their influence on the fertility of spermatozoa are reviewed. Seminal plasma can both inhibit and stimulate sperm function and fertility through the multifunctional actions of organic and inorganic components. These effects are now better understood because the composition of the seminal plasma, including its protein content and that of other structures, specifically membrane vesicles, has been clarified. Spermatozoa gain motility and fertilizing capacity as they transit the epididymis under the influence of factors produced by that organ. At ejaculation, inhibitory (termed "decapacitation") factors, sourced from the accessory sex glands, bind to the sperm surface. The major proteins isolated and characterised in ram seminal plasma, whose specific functions are yet to be determined, originate from the vesicular gland and comprise a spermadhesin together with proteins with fibronectin-II domains. In vitro handling of spermatozoa in preparation for artificial insemination (Al), involving processes such as dilution, cooling, freezing, re-warming and sperm sexing by flow cytometric sorting, can remove seminal plasma and may modify the proteins bound to the sperm surface. This destabilises the membranes and may pre-capacitate the spermatozoa, shortening their fertilizing lifespan. These changes may be reversible by seminal plasma fractions but responses differ depending on the type of sperm pre-treatment. Fertility after Al of ruminant semen may be improved if the role of seminal plasma proteins and their effect, if added individually or in combination to spermatozoa at different stages of preservation, or other manipulations such as flow cytometric sorting, can be determined.
\end{abstract}

\section{Introduction}

A large number of components, mainly proteins but also membrane vesicles, have been isolated and characterised in seminal plasma which have been associated with either positive or negative effects on sperm function and fertility. It has been hypothesised that such components, when added to spermatozoa, could either prevent or delay the natural maturation process leading to capacitation and eventual cell death (Maxwell \& Watson 1996). Other components, particularly specific protein fractions, have been identified as anti-fertility or fertilityenhancing agents and have been used, by detecting their presence in the seminal plasma, as 
indicators of the potential fertility of individual males (bulls: Killian et al. 1993; rams: Métayer et al. 2001). Moreover, factors in seminal plasma, mainly cytokines, have been implicated in conditioning the female reproductive tract, through the inflammatory response, to tolerate and facilitate embryo development and implantation (reviewed by Robertson 2005). These roles of seminal plasma in signalling in the female tract have been demonstrated to be important in rodents, humans and pigs, but are beyond the scope of this review and will be mentioned only where relevant to the survival or function of spermatozoa.

There has been considerable interest in the possibility of utilising seminal plasma, or its specific beneficial components, in the maintenance of sperm viability during processing for preservation or storage in preparation for artificial insemination (Al), or during other manipulations associated with controlled breeding, such as sex sorting (Maxwell \& Johnson 1999). These processes usually involve the removal or dilution of seminal plasma from the semen, resulting in the loss of motility, metabolic activity and fertilising capacity of spermatozoa, termed the "dilution effect" by Mann (1954). Increasing understanding of cell physiology has led to the development of buffered extenders, containing inorganic ions and organic components which have partly alleviated the problem. Nevertheless, dilution of semen also reduces the concentration of seminal plasma and any positive effect it may be having on sperm membranes. Seminal plasma has been shown to reduce the dilution effect (Maxwell \& Johnson 1999) and, when added to highly diluted semen, increases the viability of spermatozoa (rabbits: Castellini et al. 2000; cattle: Garner etal. 2001; sheep: Ashworth et al. 1994).

This review will examine the components of seminal plasma and their influence on the fertility of spermatozoa. The effects of additional seminal plasma or substitutes on the functional integrity and fertility of spermatozoa subjected to dilution, cryopreservation and sperm sexing will also be discussed. The main species of interest will be sheep and cattle, but additional insight and emphasis may be given by referring to other domesticated animals, particularly pigs and horses.

\section{Composition of seminal plasma and its effect on fertility}

The ejaculated semen of mammals comprises the spermatozoa suspended and generally swimming in a liquid medium defined as seminal plasma (Vanquelin 1791). It was initially thought that this medium was a simple filtrate of the blood that provided a nutrient-rich buffered vehicle to convey the sperm cells from the male to the female genital tract, whereupon its function ceased as the spermatozoa swam free of the plasma and commenced interaction with the fluids and cells of the female tract. Some components of the seminal plasma, such as the gel fraction found in species like the human and pig, were thought to provide a temporary physical means of retaining the spermatozoa in the female tract until they were able to establish themselves in sperm reservoirs, located further into the tract, preparatory to fertilisation (Hunter 1981).

Further functions of the seminal plasma were soon recognised. It was found that its presence, or that of a similar replacement medium, was necessary to sustain sperm viability, even for a short period of time, if the semen was held in vitro. Seminal plasma was not only a vehicle for the spermatozoa but also provided metabolic support, particularly as an energy source. The mixture of epididymal spermatozoa with seminal plasma activated their metabolic activity and motility (Mann 1964), due either to provision of special activating substances, or to dilution of inhibitory factors formerly contained in the epididymal secretion (Brooks 1990). The activation of sperm motility during epididymal transit was found to be regulated by interactions among the intracellular calcium ion concentration, cyclic AMP, adenosine and intracellular $\mathrm{pH}$ (Hoskins 
\& Vijayaraghavan 1990) as well as the phosphorylation status of specific proteins (Huang \& Vijayaraghavan 2004).

As studies on the function and fertility of spermatozoa progressed, particularly with interest in the preservation of spermatozoa for $\mathrm{Al}$, it became clear that the role of seminal plasma was more complex than that of a simple supportive or stimulatory medium. The contributions of the secretions of the epididymis and the interactions between the spermatozoa and the cells of the epididymis had profound effects on the maturity and function of the sperm cells (Cummins \& Orgebin-Crist 1971), rendering them fully functional and able to fertilise oocytes upon their sequestration in the caudal epididymis.

At ejaculation, the accessory sex gland secretions contributed different components to the seminal plasma depending on the species. The prostate, vesicular, ampullary, bulbourethral and other minor glands located in the wall of the urethral canal showed great diversity (Mann 1964), even between closely related species (Mokkapati \& Dominic 1977). The nature and effects of the secretions of these glands are still not clearly understood and are enormously variable between species. For example, the boar has large bulbourethral, prostate and vesicular glands, whilst in the ram and bull the vesicular glands are still large but bulbourethral and prostate are relatively small or disseminated. The simple explanation for these differences is that the volume and concentration of spermatozoa in the ejaculate depends on the site of semen deposition in the female tract and the length of copulation. The boar, for example, deposits a large volume of semen containing a low sperm concentration into the voluminous sow uterus during a lengthy ejaculation, whereas the bull and ram instantaneously ejaculate a small volume of highly concentrated spermatozoa into the female vagina. These differences have evolved to cope with different breeding strategies related to environmental influences.

Even within the same genus, however, the seminal plasma components can vary dramatically. In Camelids for example, the Dromedary and Alpaca, adapted to widely differing environments, produce a viscous gel ejaculate that entraps the spermatozoa until liquefaction (a process that can take several hours; Bravo et al. 2000) whereas the closely related Bactrian camel ejaculate contains little or no gel (Zhao 2000). The reasons for these differences are unclear but do not appear to be environmental or geographical adaptations.

Mann (1964) compiled what was known in the early 1960s from biochemical analyses about the major inorganic and organic components of seminal plasma. The vesicular g/ands secreted the largest volume in bulls and rams, with additional major contributions from the prostate and bulbourethral glands in boars and stallions. Nevertheless, the testes, epididymides and other accessory glands also contributed to the semen volume and, as we now know, to the important organic components of the seminal plasma and of the sperm membrane. The high water content and the presence of inorganic ions, citric acid, sugars, organic salts, prostaglandins and a number of proteins maintained the osmotic pressure of the semen and the $\mathrm{pH}$ of seminal plasma close to 7 in the bull and ram (Mann \& Lutwak-Mann 1981). Seminal plasma also provided energy sources in the form of sugars for anaerobic and aerobic respiration. Prostaglandins were found in particularly high concentrations in ram seminal plasma compared with other species (>40 $\mu \mathrm{g}$ per ml) (Mann \& Lutwak-Mann 1981). These were postulated as pharmacologic agents to aid motility and transport of spermatozoa by stimulating muscular contractions of the female tract. Prostaglandins may also have a role in the female tract as an inflammation-inducing agent, in synergy with other seminal cytokines, to promote sperm and embryonic survival (Robertson 2005). Unfortunately, it has not been possible to stimulate either sperm transport in the female tract or fertility by adding prostaglandins to diluted ram semen before Al (Salamon \& Maxwell 1995a).

Seminal plasma was found to both stimulate and inhibit the function of the spermatozoa, not surprising given our current understanding of the multifunctional nature of seminal plasma 
proteins. In the early work on capacitation, Chang (1951) and Austin (1952) showed that the spermatozoa needed to be separated from the seminal plasma and spend a period of time in association with the female tract in order to attain the capacity to penetrate and fertilise oocytes. This suggested that some inhibitory factors, termed "decapacitation factors" (Chang 1957), associated with the presence of seminal plasma needed to be removed as part of the process of capacitation. In subsequent investigations, it was demonstrated that the capacity of spermatozoa to participate in fertilisation was inhibited by seminal plasma (Chang 1957). Moreover, the fertilisable lifespan of the spermatozoa in the female tract could be extended by their exposure to the decapacitation factors present in seminal plasma (Dukelow et al. 1967).

Studies of the influence of seminal plasma components on fertility have recently focused on changes occurring during epididymal transit and on the proteome contributed from accessory sex gland secretions.

\section{Epididymal components}

The spermatozoa acquire the ability to fertilise homologous oocytes and display motility gradually during epididymal transit. The increased fertility gradient results in caudal epididymal spermatozoa with better fertility than ejaculated spermatozoa, which have been mixed with the decapacitating proteins from the accessory sex glands (Dacheux \& Paquignon 1980). Epididymal transit requires approximately 10 days in the bull and ram. Besides structural changes, spermatozoa undergo changes in the composition of the plasma membrane surface. For instance, in ram spermatozoa the molar ratio of cholesterol to phospholipid increases in the plasma membrane (Parks \& Hammerstedt 1985), as well as changes in glycoproteins of different molecular weight that bind to the sperm plasma membrane. These changes result from a direct influence of a wide range of inorganic and organic constituents of the epididymal plasma which have been described in the past (Mann \& Lutwak-Mann 1981; Robaire \& Hermo 1988) and vary considerably between different regions of the epididymis. In recent times it has become clear that the most important components influencing these changes are proteins.

The cartographies of secreted (secretomes) and present proteins (proteomes) in the epididymal fluid, and their interactions with the maturing mammalian spermatozoa have been the subject of much recent study (reviewed by Gatti et al. 2004). Significant regionalized variations in these fluid proteins along the epididymis are reflected in particular modifications of the sperm plasma membrane domains. This appears to be achieved by degradation or liberation of testicular components, the absorption and integration of secreted proteins and enzyme-mediated changes to particular membrane proteins, such as by glycosylation or deglycosylation (Dacheux et al. 2003). For example, 17- and 23-kDa proteins are restricted to the caudal epididymis in the ram and can be directly integrated in specific domains of the sperm plasma membrane. The immunolocalization of the $17-\mathrm{kDa}$ protein on the ram sperm tail suggests that it may have a role in sperm motility (Gatti et al. 2000).

Many testicular proteins in the seminal fluid, such as clusterin and transferin, disappear in the transition from the rete testis to the caput epididymis. However, more than 100 different proteins are secreted in the epididymal duct with most activity in the caput and corpus regions. The main secreted proteins are similar in different species and enzymatic activities, capable of controlling the sperm surface changes, are present in the fluid. These proteins are contained in both soluble and particulate compartments such as exosome-like vesicles (epididymosomes) and certain specific glycolipid-protein micelles (Gatti et al. 2004). Eight and 6 proteins represent most of the total epididymal secretion in the ram and bull, respectively, but in some zones only one protein can represent more than $50 \%$ of the secretion (Gatti et al. 2004). These 
proteins may be inserted and integrated into the sperm membrane during transit, with or without proteolytic processing, such as clusterin and several cysteine-rich secretory proteins (CRISP), respectively (Gati et al. 2004). Apart from the important role in regional modifications leading to the acquisition of motility and fertilizing capacity, epididymal proteins may provide protection against reactive oxygen species and bacteria, act further down the epididymis and some may be present in pro-forms that are activated after ejaculation (Dacheux et al. 2003). A number of other proteins present on the spermatozoon, which are redistributed or removed during epididymal transit, such as fertilin, cyritestin and germinal angiotensin converting enzyme (gACE), may also be important for fertility (Gatti et al. 2004).

How these different modifications in the compartments of the epididymis interplay to modify spermatozoa into fertile gametes during their transit remains to be revealed but the surfacemodifying events appear to be critically important. Having acquired the capacity to fertilise, the spermatozoa undergo further modification, under the influence of seminal plasma, to prepare them for their transport from the site of deposition in the female tract at ejaculation to the site of fertilisation in the oviduct.

Accessory sex gland components

Ejaculation results in the confluence of spermatozoa from the tail of the epididymis with various secretions from the ampullary, bulbourethral, prostate and vesicular glands. The chemical composition of the array of substances produced by these glands, and the volume of the ejaculate, are species-specific and can vary among individuals belonging to the same species. In addition, any physiological, pathological or exogenous (seasonal) conditions which change the secretory function of one or more accessory glands, can influence the amount of fluid produced and the chemical composition of the seminal plasma. For example, changes in the abundance of particular proteins in autumn compared with other times of the year (Smith et al. 1999; Gundogan \& Elitok 2004) have been correlated with seasonal changes in sperm quality parameters (Cardozo et al. 2006), freezability and resistance to cold shock in ram spermatozoa (PérezPé et al. 2001a).

The vesicular gland produces most of the semen volume and is the major source of spermsurface modifying proteins in ruminants (Bergeron et al. 2005; Fernández-Juan et al. 2006). The prostatic secretion has low protein content and the presence of free amino acids probably results from a combined action of proteases and transaminases in the glandular tissue (Mann \& Lutwak-Mann 1981). In the ram and bull, the prostate is present as disseminated glandular tissue within the wall of the pelvic urethra. It secretes fructose, citric acid as well as ergothioneine (Mann 1964). The tissues of the bulbourethral and prostate glands are major sites of local immunoglobulin production (Foster et al. 1988) and the cells of the urethral and prostatic epithelium also produce serotonin, somatostatin and chromogranin $A$, which are important for the regulation of the emission of urine and/or semen and the inhibition of local exocrine and/or endocrine secretions (Vittoria et al. 1990). The bulbourethral gland is distinguished by a high content of a sialoprotein which plays an important part in the process of "gelation" of the semen in humans and pigs (Mann 1964). There is no gel in ram, goat and bull semen but type A lecithinase secreted by this gland may be involved in the fertility of spermatozoa (Corteel 1980).

While their inorganic components help to buffer the seminal plasma and maintain sperm metabolism and osmolarity, the most important contributors to fertility and sperm function from the vesicular glands in mammals are the proteins (Table 1). These fall into two main categories: the spermadhesins or heparin-binding proteins (predominating in boar, stallion and ram) and 
those proteins that contain fibronectin type II ( $\mathrm{Fn}-2)$ domains, usually termed BSP (bovine seminal plasma) type proteins. The latter are the main proteins in bull seminal plasma (Bergeron et al. 2005).

Table 1. Major proteins originating from the vesicular glands of man and farm animals.

\begin{tabular}{|c|c|c|c|}
\hline Type of Protein & Species & Name of Prolein & References \\
\hline \multirow[t]{5}{*}{ Spermadhesins } & Boar & $\begin{array}{l}\text { AWN, } A Q N-1, A Q N-3 \text { and } \\
\text { PSPI/PSPII heterodimer }\end{array}$ & $\begin{array}{l}\text { Calvete et al. } 1995 \\
\text { Varela et al. } 1997\end{array}$ \\
\hline & Stallion & HSP-7 & Reinert et al. 1996 \\
\hline & Man & $\begin{array}{l}\text { Human spermadhesin-like protein } \\
\text { (HSA) }\end{array}$ & Kraus et al. 2005 \\
\hline & Ram & Ram spermadhesin & Bergeron et al. 2005 \\
\hline & Bull & $\begin{array}{l}\text { aSFP } \\
\text { Z13 }\end{array}$ & $\begin{array}{l}\text { Dostalova et al. } 1994 \\
\text { Tedeschi et al. } 2000\end{array}$ \\
\hline \multirow[t]{6}{*}{$\begin{array}{l}\text { Containing } \\
\text { fibronectin } \\
\text { type-ll domains }\end{array}$} & Bull & $\begin{array}{l}\text { BSP-A1, BSP-A2, BSP-A 1/A2 } \\
\text { and BSP-30kDa } \\
\text { BSP-A1/A2 also known as PDC-109 }\end{array}$ & $\begin{array}{l}\text { Manjunath \& Sairam } 1987 \\
\text { Manjunath et al. } 1987 \\
\text { Esch et al. } 1983\end{array}$ \\
\hline & Ram & $\begin{array}{l}\text { BSP-A1/A2-like prolein } \\
\text { P14 and P20 (now RSVP } 14 \text { and } \\
\text { RSVP 20) } \\
\text { RSP-15, RSP-16, RSP-22 and } \\
\text { RSP-24 kDa }\end{array}$ & $\begin{array}{l}\text { Jobim et al. } 2005 \\
\text { Barrios el al. } 2005 \text { (Fernández-Juan } \\
\text { et al.2006) } \\
\text { Bergeron et al. } 2005\end{array}$ \\
\hline & Boar & pB1 & Calvete et al. 1997 \\
\hline & Stallion & $\begin{array}{l}\mathrm{HSP}-1, \mathrm{HSP}-2 \text { and } \mathrm{HSP}-12 \mathrm{kDa} \\
\text { Fn-2 type protein }\end{array}$ & $\begin{array}{l}\text { Calvete et al. } 1995 \\
\text { Greube et al. } 2004 \\
\text { Töpfer-Pelersen et al. } 2005\end{array}$ \\
\hline & Goal & $\begin{array}{l}\text { GSP-14, GSP-15, GSP-20 and } \\
\text { GSP-22 kDa }\end{array}$ & Villemure et al. 2003 \\
\hline & Bison & $\begin{array}{l}\text { BiSV-16, BiSV-17, BiSV }-18 \text { and } \\
\text { BiSV-28 kDa }\end{array}$ & Boisverf et al. 2004 \\
\hline
\end{tabular}

A number of spermadhesins have been identified in boar seminal plasma (the AWN, AQN and PSP proteins) but only one in stallions (HSP-7; Table 1). The boar spermadhesins are further subdivided, depending on their ability to either bind heparin (AQN-1, AQN-3, AWN) or not (PSP-I/PSP-II heterodimer; Calvete et al. 1994). Proteins homologous to spermadhesins have been also found in human, ram (comprising about $40 \%$ of the protein according to Bergeron et al. 2005) and bull seminal plasma (Table 1). Proteins containing Fn-2 domains were first characterised in bull seminal plasma (BSP A1, A2, A3, A1/A2 and -30 kDa proteins). Similar proteins have been identified in ram (comprising about $20 \%$ of ram seminal plasma protein according to Bergeron et al. 2005), boar, stallion, goat and bison seminal plasma (Table 1). There are also proteins with $\mathrm{Fn}-2$ domains originating from the epididymis (Saalmann et al. 2001 ) but these may undergo modification or have only local activity related to sperm maturation. There are significant homologies between the $\mathrm{Fn}-2$ proteins identified to date in ruminants; for example, between the ram RSVP14, the ram RSP15, the bovine PDC-109 and the goat GSP-14/15 (Fernández-Juan et al. 2006).

Another class of proteins, the CRISP proteins, have been identified in a number of species. These proteins are expressed predominantly in the male reproductive tract and are implicated 
in processes ranging from spermiogenesis, post-testicular sperm maturation and capacitation to oocyte-sperm fusion (Udby et al. 2005). It is also possible that they have a role in penetration of the zona pellucida (Udby et al. 2005). They have not been implicated in the modification of sperm function in ruminants.

Many of the spermadhesins and BSP proteins have only recently been isolated and characterised in ruminant seminal plasma. An understanding of their roles in capacitation will be important to the utilization of seminal plasma as a modifier of sperm function.

\section{Seminal plasma proteins and capacitation}

Seminal plasma proteins are thought to have roles that both prevent (decapacitate) and mediate capacitation. Some vesicular gland proteins stabilise sperm membranes by binding firmly to their surface at ejaculation. As in vivo fertilisation requires a destabilisation of the membrane, as occurs during capacitation, this may explain why cauda epididymal spermatozoa are better able to fertilise oocytes in vitro than their freshly ejaculated counterparts (Dacheux \& Paquignon 1980; Nagai et al. 1984; Rath \& Niemann 1997).

The stabilising proteins are thought to be of the spermadhesin family (Romão et al. 1997). However, some of the BSP proteins may initially play a similar role in the early stages after ejaculation. For example, the BSP proteins in ram and bull seminal plasma interact with choline phospholipids on the sperm membrane, with high and low density lipoproteins and with heparin, conferring on them multifunctional biological roles in membrane stabilisation (decapacitation) and destabilisation (capacitation; Manjunath \& Thérien et al. 2001; FernándezJuan et al. 2006). On mixing with the spermatozoa at ejaculation these proteins induce cholesterol efflux from the sperm membrane (Manjunath \& Sairam 1987; Swamy 2004) resulting in reorganisation of the membrane components and, through their binding with choline phospholipids, stabilise the membrane.

As spermatozoa reach the oviducts they are exposed to follicular and oviductal fluids which contain high density lipoproteins (HDL) and heparin-like glycosaminoglycans (GAGs), the physiological capacitation factors (Rodriguez-Martinez et al. 1998). The exact signal transduction mechanism is still unclear but some BSP proteins enable spermatozoa to bind to the oviductal epithelium (Gwathmey et al. 2003) and they may possibly be involved in the release of spermatozoa from the oviductal sperm reservoir as has been shown in pigs (Jelinkova et al. 2004). Other BSPs may induce capacitation either via protein tyrosine phosphorylation (involving interaction with GAGs) or not involving protein tyrosine phosphorylation (through interaction with HDL; Therien et al. 1998; 1999). BSP-A1/A2 (PDC-109) also modulates the effects of other capacitation agents (heparin, progesterone and angiotensin II) by increasing the proportion of acrosome-reacted bull spermatozoa (de Cuneo et al. 2004).

Pig and horse spermadhesins display carbohydrate-binding activity (Calvete et al. 1995) and, like the BSP proteins, interact with the sperm surface on ejaculation. Because of their known interactions with heparin and the zona pellucida, they may be involved in capacitation (Calvete et al. 1995) and oocyte recognition (Töpfer-Petersen et al. 1998) or mediate sperm binding to the oviductal epithelium (Töpfer-Petersen 1999). The $15.5 \mathrm{kDa}$ spermadhesin identified in ram seminal plasma by Bergeron et al. (2005), which is $70 \%$ homologous with porcine AQN-1 (TöpferPetersen et al. 1998), may play a similar role in decapacitation (initially after ejaculation) and capacitation or sperm binding to the oviducal epithelium as it does in the pig, although Barrios et al. (2005) and Fernández-Juan et al. (2006) claim this "protective and restoring" role for RSVP14 and RSVP20 (Fn-2 domain proteins). This does not rule out other, yet to be elucidated, roles for porcine, bovine and ovine spermadhesins in the preparation of spermatozoa for fertilisation. 
Further proteins have been identified with decapacitating activity. These either inhibit the normal signal-transduction pathways associated with the initiation of capacitation and/or mask zona pellucida ligands on the sperm surface. ESP13.2 and PSP94, epididymal secretory proteins, coat the surface of macaque spermatozoa and are released at capacitation: ESP13.2 inhibits sperm binding to the zona pellucida when added back to the sperm surface (Tollner et al. 2004). The porcine PSP-I/PSP-II spermadhesin heterodimer is able to preserve viability and acrosome integrity, and blocks oocyte penetration by frozen-thawed but not fresh boar spermatozoa (Caballero et al. 2004a), through the prevention of sperm-zona pellucida binding (Caballero et al. 2005). RSVP14 and RSVP15 in ram seminal plasma are suggested to have a decapacitating role, stabilizing sperm membranes and protecting against cold shock when added to ram spermatozoa (Pérez-Pé et al. 2002; Barrios et al. 2005).

Recent work by Fraser and co-workers, studying mouse and human spermatozoa, has revealed important roles for a number of small peptides found in seminal plasma, which act as first messengers in the regulation of in vitro capacitation (reviewed by Fraser etal. 2006). These capacitation-inducing proteins, including adenosine, angiotensin II, calcitonin and fertilisationpromoting peptide (FPP), have been shown to stimulate CAMP production and protein tyrosine phosphorylation in spermatozoa (mouse: Mededovic \& Fraser 2004). Separate signal-transduction pathways, relevant to each peptide and involving specific receptors, have a common endpoint of increased production of the second messenger CAMP. With the exception of angiotensin II, which stimulates CAMP throughout capacitation, these signals result initially in capacitation but this is followed by an inhibition of both cAMP production and spontaneous acrosome loss, so that the capacitated spermatozoa retain their fertilising capacity. The transition from stimulation to inhibition involves loss of decapacitation factors from sperm membrane receptors, one of which has been identified in the mouse as phosphatidylethanolaminebinding protein 1 (Gibbons et al. 2005). It has been suggested that the actions of these first messengers observed in vitro, may have significant implications for enhancing or preserving fertilising capacity in vivo after the spermatozoa have been exposed to them at ejaculation (Fraser et al. 2006). Whether these roles for small peptides in signal transduction mechanisms leading to capacitation in mouse and human spermatozoa also operate in ruminant semen is yet to be determined.

\section{Fertility-associated proteins}

There have been a number of attempts to correlate the fertility potential of spermatozoa with the proteins present in the seminal plasma. The quantity of prostaglandin D synthase (PGDS; Gerena et al. 1998) and the presence of clusterin in seminal plasma (Ibrahim et al. 2000), both originating in the epididymis, have been suggested to be correlated with bull fertility. The former was later shown to be an unreliable marker as high fertility bulls had both high and low PGDS concentrations (Fouchécourt et al. 2002). Killian et al. (1993) reported the presence of four 'fertility-associated proteins' in bull seminal plasma (osteopontin, spermadhesin Z13, phospholipase A2 and BSP-30) that may improve fertility after Al with commercial dairy bull semen. Furthermore, 'anti-fertility' factors reputed to be present in the seminal plasma may bind to the sperm plasma membrane and reduce the fertility of high fertility bull spermatozoa (Henault \& Killian 1996). The 'fertility-associated proteins' identified by Killian et al. (1993) in bull seminal plasma, reported to originate from the vesicular glands, are currently under testing for commercial application by Genex Cooperative (Moura et al. 2005). Some proteins isolated from stallion seminal plasma have also been positively correlated with fertility and may have commercial application (Brandon et al. 1999). 
Gatti et al. (2004) hypothesized that abnormal gACE levels in ram seminal plasma (released from spermatozoa during epididymal transit) could be an indicator of an interruption to sperm maturation, as the quantity of gACE is correlated with the number of spermatozoa. The correlation of gACE activity with the number of spermatozoa in the ejaculates of young rams had been confirmed (Métayer et al. 2001) and low gACE levels were associated with lower fertility (Gatti et al. 2004). Anti-sperm antibodies (AS,A) have also been identified, particularly those associated with infertility in men. For example, Carlsson et al. (2004) reported that prostasomes adhered to human spermatozoa were major targets for ASAs and identified PIP (prolactin-inducible protein) and clusterin as dominant antigens for sperm-agglutinating autoantibodies. The usefulness or otherwise of these correlations as a basis for assessment of individual males or of their ejaculates, and their application in semen processing and preservation, is yet to be determined.

The possibility of fertility-associated proteins in seminal plasma and on the sperm surface needs to be considered in the context of new research on the relationship between Major Histocompatability Complex $(\mathrm{MHC})$ haplotype and mating outcome. This work suggests a connection between the $\mathrm{MHC}$ and both pre- and post-copulatory female choice of the spermatozoon participating in fertilisation. This is based on the crucial importance of the $\mathrm{MHC}$ in immune responses, resulting in an evolutionary female preference for mates that are $\mathrm{MHC}$ heterozygous and unique (Ziegler et al. 2005). The proposed mechanism of action is through chemoreceptors, which operate in mate choice, not only through nasal odorant receptors (Buck \& Axel 1991) but also through guidance cues for spermatozoa (Spehr et al. 2003; Robertson 2005). Osteopontin, for example, one of the fertility-associated proteins in bovine seminal plasma (Killian et al. 1993) is a ubiquitous cell adhesion component involved in cell migration, chemotaxis and macrophage activation (Moura 2005). PSP-I and PSP-II may not play a role in capacitation or sperm-oocyte binding but rather display proinflammatory effects which modulate immune responses in the porcine uterus (Assreuy et al. 2002).

The hidden female effects that impact on the success of males in fertilizing ova have been labelled 'cryptic female choice' (Eberhard 1996) and relate partly to sperm competition mediated by mutual recognition of seminal plasma components (including soluble $\mathrm{MHC}$ antigens and those sequestered on the sperm surface) by spermatozoa from different males and/or by the female reproductive tract (Ziegler et al. 2005). Thus, in humans, the sharing of MHC alleles between partners may influence the occurrence of certain forms of human sterility and recurrent spontaneous abortions (Beydoun \& Saftlas 2005). There is also evidence for MHC compatibility involvement in oocyte penetration and within the penetrated oocyte by influencing the outcome of the second meiotic division (Wedekind et al. 1996). It is possible that some of the fertility-associated proteins may either be the result of $\mathrm{MHC}$ expression or be masking ligandreceptor mechanisms that might normally block either sperm function or fertilisation.

\section{Seminal plasma vesicles}

It has been known for a long time that small vesicles are present in the seminal plasma of several mammals. These are roughly spherical organelles containing dense particles that are delimited by single, double or multiple membranes, and range in diameter from 21 to nearly $1000 \mathrm{~nm}$ (Table 2). The vesicles generally have been named after the accessory organ from which they were thought to originate. The membranous vesicle fraction identified in human seminal plasma, for example, was initially named pellet II (Ronquist et al. 1978a; 1978b) and later "prostasomes" (Brody et al. 1983) or "epididymosomes" (Saez et al. 2003) because of its prostatic or epididymal origin. Prostasomes in human seminal plasma, or prostasome-like membrane vesicles in equine seminal plasma, are particles made up of lipid and protein. It has been 
hypothesized that these may assist the fertilizing potential of spermatozoa by adhering to and fusing with them, decreasing the fluidity of the sperm membrane, thereby delaying the acrosome reaction and improving the motility and viability of spermatozoa, especially as they enter the female genital tract (Minelli et al. 1998; Minelli et al. 1999; Kravets et al. 2000).

Table 2. Size of vesicles idenlified and characterised in the seminal plasma of man and farm animals.

\begin{tabular}{|c|c|c|}
\hline Species & Vesicle diameter range ( $\mathrm{nm}$ ) & References \\
\hline Man & $21-100$ & Ronquist et al. 1978a; 1978b \\
\hline Ram & $\begin{array}{l}50-300 \\
22-986(\text { mean } 159.7 \pm 2.92)\end{array}$ & $\begin{array}{l}\text { Breitbart and Rubinstein } 1982 \\
\text { El-Haij Ghaoui et al: } 2004\end{array}$ \\
\hline Boar & $18-577($ mean $130.9 \pm 3.22)$ & El-Haij Ghaoui et al. 2004 \\
\hline Stallion & $\begin{array}{l}75-175 \mathrm{~nm} \\
15-671 \text { (mean } 164,1 \pm 4.42)\end{array}$ & $\begin{array}{l}\text { Minelli et al. } 1998 \\
\text { El-Haji Ghaoui et al. } 2004\end{array}$ \\
\hline
\end{tabular}

The fusion between prostasomes and spermatozoa (Carlini et al. 1997) may stabilise the sperm plasma membrane by enriching it with cholesterol, sphingomyelin, and saturated glycerophospholipid (Arienti et al. 1997). This is postulated to prevent the occurrence of capacitation and the acrosome reaction by producing a transient increase of intracellular calcium ion concentration (Palmerini et al. 1999). Others have suggested that human prostasomes may improve the recovery of hyperactively motile spermatozoa and consequently increase the opportunities for fertilisation (Fabiani et al. 1994). Likewise, prostasome-like membrane vesicles identified in the seminal plasma of the stallion and the occurrence of a fusion-like process between these vesicles and the sperm cells suggests that they may play a physiological role in the fertilizing capacity of equine spermatozoa (Arienti et al. 1998). These roles for membrane vesicles in capacitation and/or fertilisation have yet to be supported by convincing experimental evidence.

Breitbart \& Rubinstein (1982) first isolated vesicular membranes from ejaculated ram seminal plasma and demonstrated the presence of divalent-cation-dependent ATP-ase associated with them. Vesicles with a specific protein content, and in association with cellular protein isoforms, have been identified also in the cauda epididymal secretions of the ram (Ecroyd et al. 2004). These were shown to form the majority of the vesicles retrieved in the seminal plasma of the ram and were called epididymosomes (Gatti et al. 2005). By examining the seminal plasma of vasectomized and entire rams, we demonstrated that the membrane vesicles in ram seminal plasma do not originate from the accessory sex glands (El-Hajj Ghaoui et al. 2006). A comparison of the morphology of vesicles in the seminal plasma and the cytoplasmic droplets by transmission electron microscopy led us to conclude that, at least in the ram, the vesicles originate from a combination of the droplets and the epididymis (El-Haji Ghaoui et al. 2006). It should be noted, however, that the absence of vesicles from the seminal plasma of vasectomised rams does not completely preclude their presence in the accessory sex glands. For example, "secretomes" identified by immunostaining in the vesicular glands of rams as localized sites of RSVP-14 production, may provide an apocrine mechanism for releasing the protein, whereupon the vesicle carriers break down in the lumen of the gland (Fernández-Juan et al. 2006).

The biological importance and the functions of membrane vesicles in ram seminal plasma are still obscure. Based on the data from other mammalian species, these membrane vesicles 
may be involved in capacitation and have the potential to influence the fertility of spermatozoa. It may be possible to incorporate these vesicles with different seminal fluid extenders in order to improve fertility after semen preservation and AI.

\section{Addition of seminal plasma to spermatozoa}

Reports are somewhat equivocal on the benefits or otherwise of seminal plasma in association with spermatozoa of various species during artificial preservation. For example, early researchers on frozen storage of boar spermatozoa recommended that removal of the seminal plasma, after initial holding in its presence, was beneficial to post-thaw sperm survival (Pursel \& Johnson 1975). More recently, the addition of seminal plasma to boar spermatozoa was reported to be detrimental to sperm survival during post-thaw incubation (Erickson et al, 2005) but 20\% seminal plasma prevented or reversed capacitation-like changes of boar spermatozoa, as detected by the chlortetracycline assay, resulting from incubation at $39^{\circ} \mathrm{C}$ or cooling to $5^{\circ} \mathrm{C}$ (Vadnais et al. 2005). Removal of seminal plasma and resuspension with artificial media is also reported to improve the survival and DNA integrity of stallion spermatozoa during chilled storage (Love et al. 2005). Seminal plasma is generally removed from equine spermatozoa before cryopreservation as it is deleterious to sperm survival if they are exposed to it for a prolonged period before freezing (Moore et al. 2005).

Conversely, in ruminants, Ashworth et al. (1994) identified beneficial proteins 5-10kDa in size that reduced the adverse effects of dilution on ram spermatozoa. Moreover, fertility of frozen-thawed ram spermatozoa after cervical insemination was improved after addition of seminal plasma (Maxwell etal. 1999) although it is not known whether the addition of seminal plasma components is beneficial to fertility of frozen-thawed bull spermatozoa.

One explanation for these apparent contradictions is the relative ratio of capacitating and decapacitating, or possibly beneficial and harmful, proteins in seminal plasma, and their variation between species or even individuals and within individual males over time. It should be noted that whole seminal plasma is a complex mixture of organic and inorganic components, as well as proteins with positive and negative effects. The concentrations of these proteins vary from male to male and can appear and disappear depending on environmental factors such as season of collection, temperature, nutrition and stress (Pérez-Pé et al. 2001b). Most research to date on the addition of seminal plasma to spermatozoa has not controlled for this within male variation.

Moreover, the beneficial effects of seminal plasma are likely to be restricted to specific proteins and these may be negated by harmful effects of other factors present in whole seminal plasma. For example, García-López et al. (1996) demonstrated that protein-free ram seminal plasma contains a low molecular weight factor that interferes with the viability-stimulating effect of isolated plasma proteins, possibly by preventing their adsorption to the sperm surface, The adsorption of beneficial proteins will also depend on the origin of the spermatozoa (eg epididymal, ejaculated, oviductal) and whether they have been subjected to manipulations such as dilution or cryopreservation. These treatments may act to strip proteins from spermatozoa, revealing ligands and binding sites that render them more susceptible to interactions, such as those associated with: capacitation and the (false) acrosome reaction; cell death; or more readily able to interact with and penetrate oocytes.

The influence of seminal plasma may also depend on the other components of the medium in which the spermatozoa are extended. In the presence of egg yolk, for example, Manjunath et al. (2002) claim that the 14, 15 and $16 \mathrm{kDa}$ RSP proteins, suggested to be detrimental to sperm survival, would be bound to and rendered inactive by the yolk low density lipoprotein fraction allowing the beneficial or decapacitating protein(s) to bind to the sperm head. 
When a detailed understanding is gained of the roles of the main seminal plasma proteins in the normal maturation, transport and preparation of spermatozoa for fertilisation after deposition in the female reproductive tract, it may be possible to utilise specific proteins to improve or enhance the function of spermatozoa that have been compromised through processing and storage for AI. For the present, there have been a number of studies on the addition of whole seminal plasma, or crude fractions of it, to spermatozoa that have been through such processes. The final section of this review outlines the known effects of frozen storage and sex-sorting by flow cytometry on the function and capacitation status of ram spermatozoa. It also considers current evidence for the benefit, or otherwise, of adding seminal plasma or its membrane vesicles to frozen-thawed and sex-sorted spermatozoa of several different species.

The potential benefits of seminal plasma to the fertility and function of frosen-thawed ram spermatozoa

Seminal plasma alone is not sufficient to protect ram spermatozoa against cold shock. Therefore, the extenders or diluents used for cryopreservation need to contain components that will potentially decrease sperm cryoinjury (Salamon \& Maxwell 1995a). The function of spermatozoa is sustained for many years by frozen storage (Gillan et al. 2004), but their fertilizing ability, especially after cervical insemination, is much lower than for fresh diluted spermatozoa (Gillan \& Maxwell 1999). Although recent Scandinavian studies report 25 day non-return rates above $70 \%$ after cervical insemination with frozen-thawed semen (Paulenz et al. 2005) the standard pregnancy rates in Australia are closer to 20\% (Maxwell \& Hewitt 1986).

The development of intrauterine insemination by laparoscopy has largely overcome this problem (Salamon \& Maxwell 1995b) but there are ethical limitations to the continued use of this invasive procedure and it may be necessary to revert to cervical insemination. For this reason, there has been considerable interest in the effects of seminal plasma and its constituents on sperm quality after freeze-thawing. For example, when either whole ram seminal plasma or its $>10 \mathrm{kDa}$ protein fraction were added to the diluent, acrosome and plasma membrane integrity, motility, and sperm heterogeneity after thawing were significantly improved (Ollero et al. 1997). Furthermore, improved sperm motility, a reduction in the proportion of capacitated and acrosome reacted cells, and increased ability to penetrate cervical mucus were obtained after addition of seminal plasma to frozen-thawed ram semen (Maxwell et al. 1999).

Capacitation-like changes in frozen-thawed spermatozoa and their possible reversal by seminal plasma

A limitation to extended viability of frozen-thawed spermatozoa in the female tract is the socalled "pre-capacitated" state in which a high proportion of the cells emerge after freezethawing (Cormier et al. 1997; Maxwell \& Johnson 1997b; Gillan \& Maxwell 1999; Cormier \& Bailey 2003) since their membranes become permeable to calcium ions, leading to the (false) acrosome reaction and cell death. During "normal" sperm capacitation, the spermatozoon becomes highly polarized and its plasma membrane shows regional specialization with changed characteristics and composition (Guraya 2000). The changes in sperm cells as a result of freezing and thawing have been identified as "capacitation-like" (Watson 1995; Maxwell \& Watson 1996) because they resemble the late steps in the signal transduction pathway that leads from capacitation to the acrosome reaction, as identified by the fluorescent membrane probe chlortetracycline (Cormier et al. 1997; Gillan \& Maxwell 1999), and they render the sperm func- 
tionally capacitated in both their ability to fertilise oocytes in vitro (Maxwell \& Watson 1996) and interact with oviduct epithelial cells (Gillan et al. 2000).

While these capacitation-like changes are clearly not true capacitation (Green \& Watson 2001), recent work on sperm cryopreservation has focused on the role of seminal plasma in the stabilisation of sperm membranes as well as the identification and separation of its decapacitation factors (Guraya 2000). This is potentially important as, once the sperm membrane becomes fully capacitated, the spermatozoa only have a limited lifespan in which to find and fertilise the ovum. It may be that all the surface changes which occur in spermatozoa during capacitation, for example cholesterol efflux (Parks \& Ehrenwald 1989; Cross 1998; 2003), alteration in the protein composition of the surface (Myles et al. 1990), or changes in the distribution of intramembranous particles (Yanagimachi 1988; Suzuki-Toyota et al. 2000), are influenced by changes to the proteins initially contributed by the seminal plasma and bound to the spermatozoa. It is thought that these decapacitating factors in seminal plasma are removed or modified during the transit of the spermatozoa through the female genital tract and, if added to frozenthawed spermatozoa, would extend their longevity by binding, or re-binding, to the plasma membrane and inhibiting further structural and physiological changes (Fraser et al. 1990; Maxwell \& Johnson 1999; Guraya 2000; Barrios et al. 2000; Wolfe et al. 2001; Barrios et al. 2005).

The recent published literature on spermatology poses several hypotheses on the nature of decapacitation factors, their function and their presence on the spermatozoa themselves or in their surroundings. A number of these have been tested, mainly in vitro, in non-ruminant species but few have been applied experimentally to ruminant spermatozoa. However, there is considerable evidence of a direct effect of whole seminal plasma and its fractions on the function of frozen-thawed and processed ruminant spermatozoa.

Function of frozen-thawed spermatozoa after addition of seminal plasma fractions and membrane vesicles

In studies on frozen-thawed ram spermatozoa, we found that sperm function and fertility were improved by the post-thaw addition of whole seminal plasma (Maxwell et al. 1999). We hypothesised that the beneficial components in seminal plasma would be in its vesicle-free fraction and that this fraction would be active in both entire and vasectomised rams. In other words, the beneficial components of seminal plasma were likely to be of post-epididymal origin and probably proteins from the vesicular gland. Thermal denaturation of whole seminal plasma removed its protective effect on frozen-thawed (CA McPhie, 5 Mortimer, WMC Maxwell \& G Evans, unpublished observations) and cold-shocked ram spermatozoa (García-López et al. 1996), confirming that the active constituent was proteinaceous. We further postulated that the membrane vesicle fraction of seminal plasma either had no function, or had a role in sperm maturation and membrane function confined to the epididymis, and would not influence the function or fertilizing capacity of frozen-thawed spermatozoa.

We first isolated membrane vesicles from ram seminal plasma, purified them by size exclusion chromatography and defined their structure (El-Hajj Ghaoui etal. 2004). Next, we demonstrated that vasectomy eliminated the membrane vesicles from ram seminal plasma (El-Hajj Ghaoui etal. 2006), indicating that they were of testicular or epididymal origin. Whole seminal plasma collected before and after vasectomy of four rams was separated by ultracentrifugation into two fractions; supernatant and a pellet of vesicles. The protein profiles of these fractions, characterised by SDS-PAGE, were in the same molecular weight ranges as those identified by Bergeron et al. (2005) and Fernández-Juan et al. (2006) for entire rams (Fig. 1). 

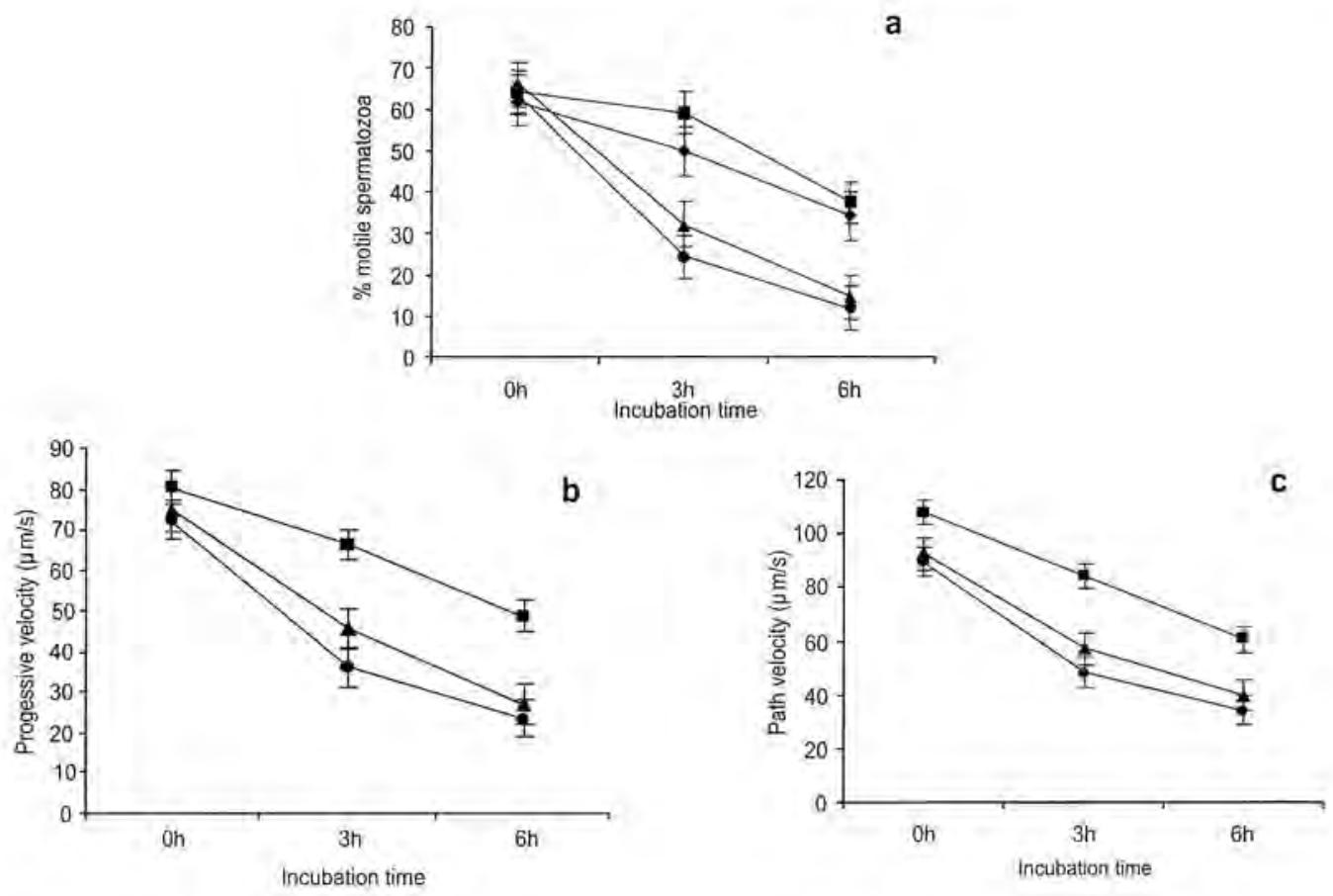

Fig. 2. The motility characteristics of frozen-thawed ram spermatozoa during $6 \mathrm{~h}$ incubation at $37^{\circ} \mathrm{C}$ with $(\bullet)$ control buffer, ( $(\bullet)$ whole seminal plasma, $(\boldsymbol{\Delta})$ vesicles at their normal concentration or $(\bullet)$ vesicles at $3 \mathrm{X}$ their concentration. Panel a: motility (\%, determined subjectively), panel b: progressive velocity (VSL, $\mu \mathrm{m} \cdot \mathrm{sec}^{-1}$ determined by CASA; HTM-IVOS; HamiltonThorne, USA) and panel c: average path velocity (VAP, $\mu \mathrm{m} \cdot \mathrm{sec}^{-1}$, determined by CASA). Data are presented as mean \pm s.e.m. (REl-Haji Ghaoui, L Gillian, PC Thomson, G Evans and WMC Maxwell, unpublished observations).

mammalian spermatozoa by flow cytometric sorting. Extensive dilution of semen and insemination with a low number of spermatozoa in cattle have been standard means of applying this technology (Johnson 2000). The sperm sexing technique, based on the difference in DNA between $X$-and Y-chromosome-bearing spermatozoa (Moruzzi 1979), requires an extensive dilution of the spermatozoa before and after sorting but this dilution is detrimental to the motility, membrane status and fertilizing capacity of the spermatozoa (Maxwell \& Johnson 1997a). In order to minimize this dilution effect, sorted spermatozoa are collected into a tube containing either an egg yolk extender (Johnson 2000) or seminal plasma may be included as a portion of the staining extender and the collection medium (Maxwell et al. 1997; Maxwell \& Johnson 1999; Centurion et al. 2003).

Catt et al. (1997) showed that 10\% ram or boar seminal plasma in the diluent increased motility and viability of ram or boar spermatozoa in semen that had been extended 400- or 20fold, respectively. While the viability of ram spermatozoa (percentage live as assessed by nonpenetration of nuclear membrane by propidium iodide) was improved by seminal plasma, this was partly due to a decrease in the proportion of agglutinated cells. Interestingly, heterologous seminal plasma is generally detrimental (boar with ram or ram with boar: Catt et al. 1997; CA McPhie, S Mortimer, WMC Maxwell \& G Evans, unpublished observations; bull with ram: Garcia-López et al. 1996), autologous plasma is usually beneficial (male with the same male) 
a

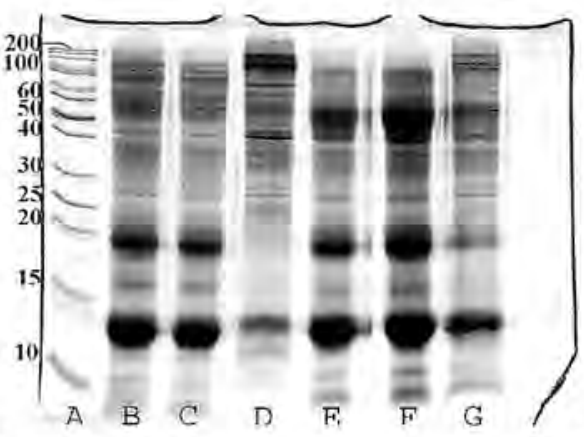

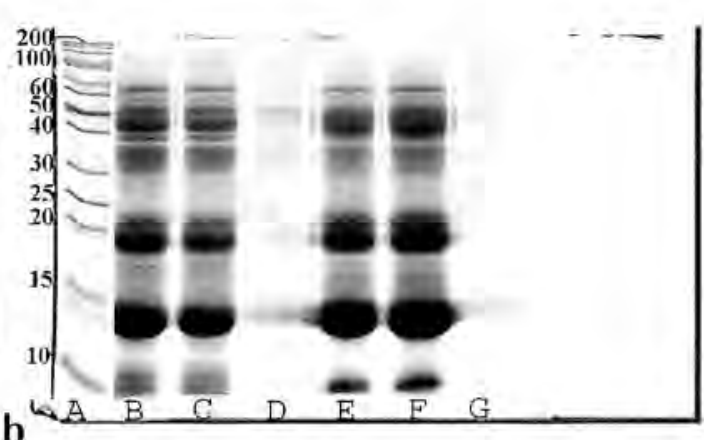

b

Fig. 1. SDS-PAGE pattern of whole seminal plasma and its fractions before (a) and after (b) vasectomy from the same ram. Samples were standardized $(20 \mu \mathrm{g}$ protein in $12 \mu \mathrm{l})$ denatured, reduced and separated on $15 \%$ polyacrylamide gel and stained with Coomassie Blue R-250. Lane A: Protein marker (PageRuler Protein Ladder; Progen Industries Ltd., Darra, QId, Australia); lanes B and E: whole seminal plasma; lanes C and F: supernatant; lanes $\mathrm{D}$ and $\mathrm{G}$ : pellet of vesicles. Whole seminal plasma was obtained by centrifugation and washing (twice: $2500 \times \mathrm{gg}, 4^{\circ} \mathrm{C}, 30 \mathrm{~min}$ ) of 12 and 8 whole ejaculates, collected before and after vasectomy, respectively, and pooled within ram. Supernatant and pellet fractions were obtained by ultracentrifugation of whole seminal plasma $\left(100,000 \times \mathrm{g}, 4^{\circ} \mathrm{C}, 80 \mathrm{~min}\right) .1$ (RSP-22 kDA and RSP-24 kDa, or RSVP-20) and 2 (RSP-15 $\mathrm{kDa}, \mathrm{RSP}-16 \mathrm{kDa}$ and $15.5 \mathrm{kDA}$ spermadhesin, or RSVP-14) indicate the approximate positions of the major proteins in ram seminal plasma (Bergeron et al. 2005; or FernándezJuan et al. 2006, respectively). (R El-Hajj Ghaoui, L Gillian, PC Thomson, G Evans and WMC Maxwell, unpublished observations).

Regardless of vasectomy, whole seminal plasma and supernatant improved motility characteristics of frozen-thawed ram spermatozoa (Fig. 2: R El-Hajj Ghaoui, L Gillian, PC Thomson, G Evans and WMC Maxwell, unpublished observations) and improved the ability of spermatozoa to fertilise in vitro matured oocytes (Fig. 3: R El-Hajj Ghaoui, L Gillian, PC Thomson, G Evans and WMC Maxwell, unpublished observations). The membrane vesicle fraction from plasma collected before vasectomy had no effect on spermatozoa at its normal concentration but marginally increased fertilizing capacity of frozen-thawed spermatozoa when included at three times normal concentration in the incubation medium (Fig. 3). This may be due to protein remnants still associated with the vesicle fraction, rather than the vesicles themselves, Protein bands were identified by SDS-PAGE in the vesicle fraction of entire rams (Fig. 1a, lanes D and G) although in low abundance, particularly the $20 \mathrm{kDa}$ protein. In vasectomised rams, however, only one faint protein band at $15 \mathrm{kDa}$ was apparent in the vesicle fraction (Fig. $1 b$, lanes D and G).

These findings confirm our previous reports on the beneficial effects of whole seminal plasma on the function and fertility of frozen-thawed ram spermatozoa (Maxwell et al. 1999), and suggest that the beneficial components of the seminal plasma are largely contained in its non-vesicle protein fraction.

Function of sex-sorted spermatozoa after addition of whole and artificial seminal plasma

While exposure of spermatozoa to additional seminal plasma after freezing and thawing can improve their viability, the removal of seminal plasma during processing can also decrease the viable life-span of spermatozoa. An example of this is the dilution associated with the sexing of 


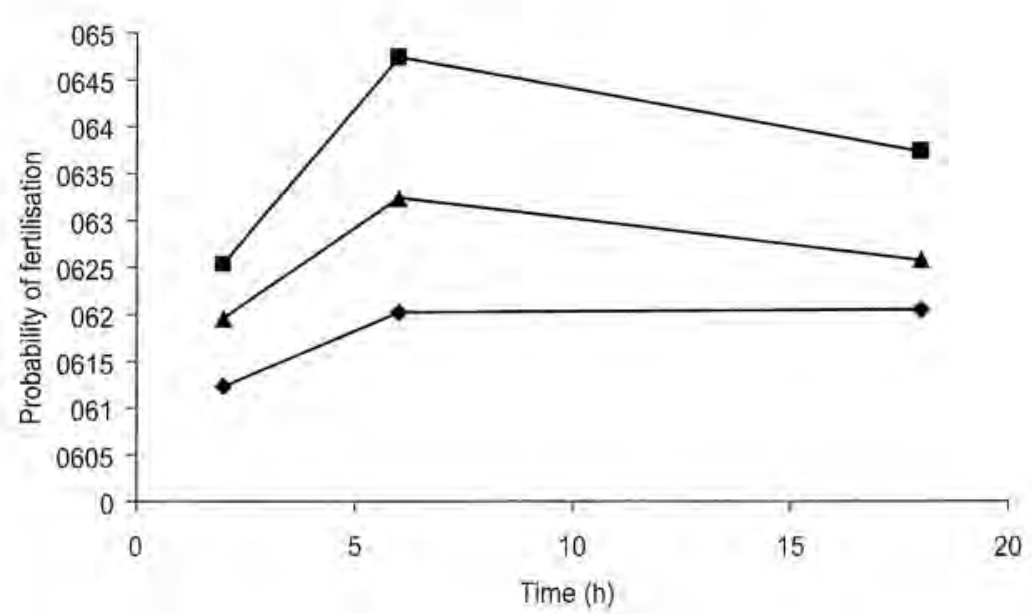

Fig. 3. The probability of in vitro fertilisation after 2,6 and $18 \mathrm{hr}$ co-culture of in vitro matured sheep oocytes with frozen-thawed ram spermatozoa, previously incubated $\left(37^{\circ} \mathrm{C}\right.$, $3 \mathrm{hr}$ ) with ( $\bullet$ control buffer, ( $\mathbf{-})$ supernatant $(20 \%, v / v$ in buffer) or ( $\mathbf{\Delta})$ pellet of vesicles at $3 \mathrm{x}$ normal concentration ( $20 \%, v / v$ in buffer). Whole seminal plasma was obtained by centrifugation and washing (twice: $2500 \mathrm{xg}, 4^{\circ} \mathrm{C}, 30 \mathrm{~min}$ ) of whole ejaculates pooled within ram. Supernatant and pellet fractions were obtained by ultracentrifugation of whole seminal plasma $\left(100,000 \times \mathrm{g}, 4^{\circ} \mathrm{C}, 80 \mathrm{~min}\right)$. Oocytes (3 replicates of 315,341 and 198 ) were matured and in vitro fertilisation $\left(1 \times 10^{6}\right.$ motile spermatozoa per $\left.\mathrm{ml}\right)$ occurred in IVF complete medium (Cook IVF, Brisbane, Australia). After co-culture, oocytes were fixed and stained with aceto-Orcein and examined (phase contrast, 600x magnification) for evidence of fertilisation. The probability of fertilisation was determined from the binary data (fertilised or unfertilised) by fitting a generalised linear mixed model (GLMM) using GenStat 8. (R El-Hajj Ghaoui, L Gillian, PC Thomson, G Evans and WMC Maxwell, unpublished observations).

but the effects of homologous plasma vary with the donor male and can be negative (ram and bull: CA McPhie, S Mortimer, WMC Maxwell \& G Evans, unpublished observations; boar: Caballero et al. 2004b). The beneficial components of boar seminal plasma, in the case of highly diluted boar spermatozoa, have been isolated to the PSP-II subunit of the PSP-I/PSPII spermadhesin (Garcia et al. 2006). In the case of ram seminal plasma the beneficial proteins may be RSVP-14/20 (Barrios et al. 2005) or ram spermadhesin (Bergeron et al. 2005) but these have been less clearly defined for ram and bull as the reported effects of seminal plasma on highly diluted and sex-sorted spermatozoa are equivocal in these species (see below).

The viability and membrane integrity of spermatozoa was improved in vitro if seminal plasma was included in the staining extenders for boar and ram spermatozoa or in the collection medium for boar or bull spermatozoa (Maxwell et al. 1997), It was concluded that the beneficial effects in the staining extender reflected a reduction of the 'dilution effect' and in sperm agglutination, whereas seminal plasma in the collection medium stabilised sperm membranes and prevented premature cell death independent of effects on sperm motility (Maxwell \& Johnson 1999). Proportions of boar spermatozoa with capacitation-like changes were lower when seminal plasma was present in the collection medium only, than in the staining extender or absent altogether, but the former treatment substantially reduced the proportions of polysper- 
mic, penetrated and cleaved oocytes, and the proportion of blastocysts. These findings suggested that capacitation-like changes in boar spermatozoa associated with flow-cytometric sorting could be reduced by the inclusion of seminal plasma in the collection medium but this treatment reduced the ability of spermatozoa to fertilise oocytes in vitro under these conditions (Maxwell etal. 1998): Whether similar effects would result from seminal plasma in the staining and collection media used for ram and bull spermatozoa were not determined (Maxwell \& Johnson 1999).

The results of Maxwell et al. (1997) and Catt et al. (1997) were obtained using a modified Coulter Epics V flow cytometer with a 7-W argon laser (170 $\mathrm{mW}$; ultra-violet) and operating at a sheath pressure of 20 psi. In the case of ram semen, the spermatozoa were diluted before sorting at 500-1000 fold (around ten times that required for boar spermatozoa) in preparation for staining with the DNA-permeant Hoechst 33342 fluorochrome that distinguishes X-from Ybearing cells. This was followed by a second dilution by sheath fluid (phosphate-buffered saline supplemented with bovine serum albumin) and collection medium resulting in a final dilution of up to 30,000-fold. Compared with low-speed sorting with the Coulter machine, our current studies utilize a high-speed flow cytometer ( $\mathrm{SX} \mathrm{MoFlo}{ }^{-2}$ ) operating at a sheath pressure of 40 psi with a TRIS-based sheath fluid. The diode-pumped solid state pulse laser, operating at 125 $\mathrm{mW}$, results in less exposure of individual spermatozoa to ultra-violet light than the argon laser. The spermatozoa undergo less dilution before and after sorting, because of the increased speed of sorting (5-10,000 compared with 1400 spermatozoa sec-1), resulting in a final dilution rate of about 5000-fold, and the spermatozoa are exposed to the sheath and collection medium for a shorter period of time (15-30 $\mathrm{min})$ compared to low speed sorting (60 min).

Under these high speed sorting conditions, whole seminal plasma does not provide the same benefits to sorted ram spermatozoa that have been subsequently frozen and thawed, compared to non-sorted frozen-thawed spermatozoa (Maxwell et al. 2004). Sex-sorting of ram spermatozoa using MoFlo technology improved motility $(64.7 \pm 4.8$ vs. $43.1 \pm 4.0 \%, P<0.05)$, viability $(53.4 \pm 4.0$ vs. $36.5 \pm 3.4 \%, P<0.05)$ and mitochondrial activity $(63.1 \pm 4.7 \mathrm{vs}, 41.3 \pm 3.9 \%$ respiring, $P<0.05$ ) of spermatozoa compared with a non-sorted population but reduced the forward progressing velocity of sex-sorted cells (measured by CASA; VAP: $83.0 \pm 3.8$ vs. $97.1 \pm 6.9$ $\mu \mathrm{m} . \mathrm{sec}-1, P<0.05)$ and their ability to penetrate cervical mucus $(22.0 \pm 3.5 \mathrm{vs} .43 .3 \pm 3.8$ spermatozoa penetrated $1 \mathrm{~cm}, P<0.05$; for sorted vs. control spermatozoa, respectively) ( $\$$ de Graaf, WMC Maxwell \& G Evans, unpublished observations). These differences were retained when the sorted or non-sorted spermatozoa were incubated for 6 hours (Fig. 4: $S$ de Graaf, WMC Maxwell \& G Evans, unpublished observations).

The improvement in sperm motility and viability in the flow-sorted population is not surprising, as the cells are stained before sorting with a dye (originally propidium iodide but now a non-toxic food dye) that penetrates the nuclear membrane of non-viable cells, staining the nucleus red, and allowing these cells to be gated out to waste during flow sorting. The reduction in kinematics and sperm transport may explain the lower fertility obtained after Al of ewes with low (2-4 million) compared with high (20 million) doses of sex-sorted, frozen-thawed spermatozoa (Maxwell et al. 2004). Nevertheless, we have recently obtained indistinguishable fertility when sufficient numbers (15 million motile) of control or sex-sorted ram spermatozoa - or even frozen-thawed, sex-sorted, re-frozen and re-thawed spermatozoa-are deposited in the uterus of synchronised ewes by laparoscopic insemination (SP de Graaf, G Evans, WMC Maxwell, DG Cran \& JK O'Brien, unpublished observation). The latter results demonstrate that the highly-selected population of spermatozoa resulting from sex-sorting by flow cytometry, interjacent with two rounds of freezing and thawing, are capable of normal fertility when placed in reasonable proximity to the site of fertilisation close to the time of ovulation. 

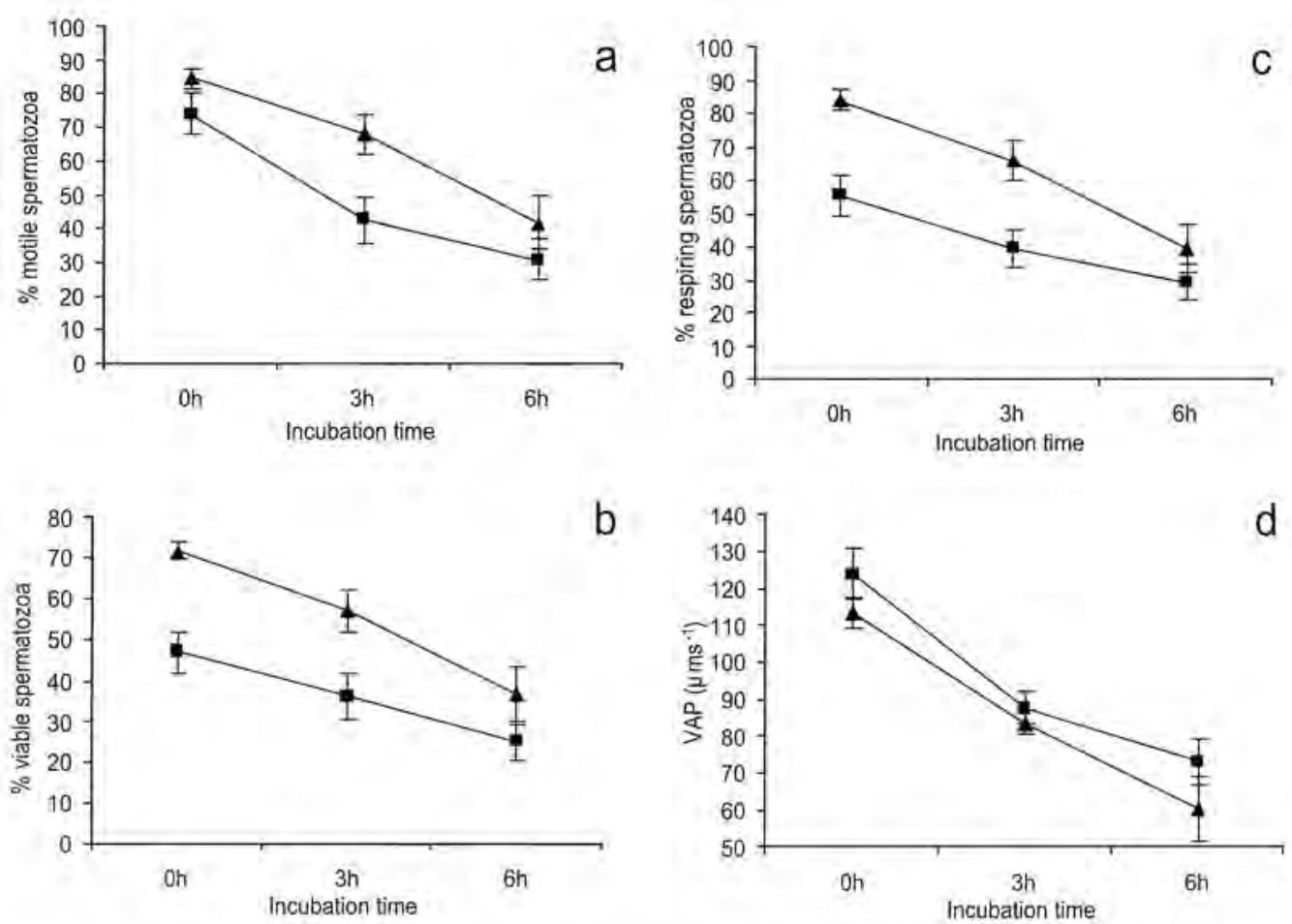

Fig. 4. The motility characteristics, viability and mitochondrial activity of [ $\mathbf{\square}$ ] unsorfed or [ $\mathbf{\Lambda}$ ] sex-sorted frozen-thawed ram spermatozoa during $6 \mathrm{~h}$ incubation at $37^{\circ} \mathrm{C}$. Panel a: motility ( $\%$, determined by CASA; HTM-IVOS; Hamilton-Thorne, USA), panel b: viability ( $\%$ live spermatozoa assessed by exclusion of ethidium homodimer-1), panel c: mitochondrial activity (\% respiring sper matozoa, assessed by accumulation of $\mathrm{R} 123$ in the midpiece) and panel d: average path velocity (VAP, $\mu \mathrm{m} \cdot \mathrm{sec}^{-1}$, determined by CASA). Data are means \pm s.e.m. (S de Graaf, WMC Maxwell \& G Evans, unpublished observations).

The addition of whole seminal plasma, or an artificial seminal plasma (ASP) based on its inorganic composition and unlikely to influence sperm membrane status ( $\mathrm{O}^{\prime}$ Donnell 1969), to frozen-thawed ram spermatozoa improves its motility and movement characteristics assessed by CASA (Mortimer \& Maxwell 2004). However, if the spermatozoa have been sex-sorted before freezing, both whole seminal plasma and ASP are detrimental to sperm motility and velocity (Fig. 5: S de Giaaf, WMC Maxwell \& G Evans, unpublished observations). With increasing proportions of whole seminal plasma in the post-thaw medium, the motility, viability, velocity and mitochondrial activity of sex-sorted, frozen-thawed spermatozoa decline, compared with non-sorted, frozen-thawed spermatozoa (Fig. 6: S de Graaf, WMC Maxwell \& G Evans, unpublished observations). Moreover, the use of ASP as sheath fluid does not attenuate the effects of flow cytometric sorting. While initially improving post-sort kinematics, ASP markedly decreases post-thaw motility and longevity compared with a TRIS-based sheath fluid (de Graaf et al. 2004).

While these results at first seem contradictory, evidence is now emerging that the effects of seminal plasma are not simply confined to decapacitation (after addition) and capacitation (after 


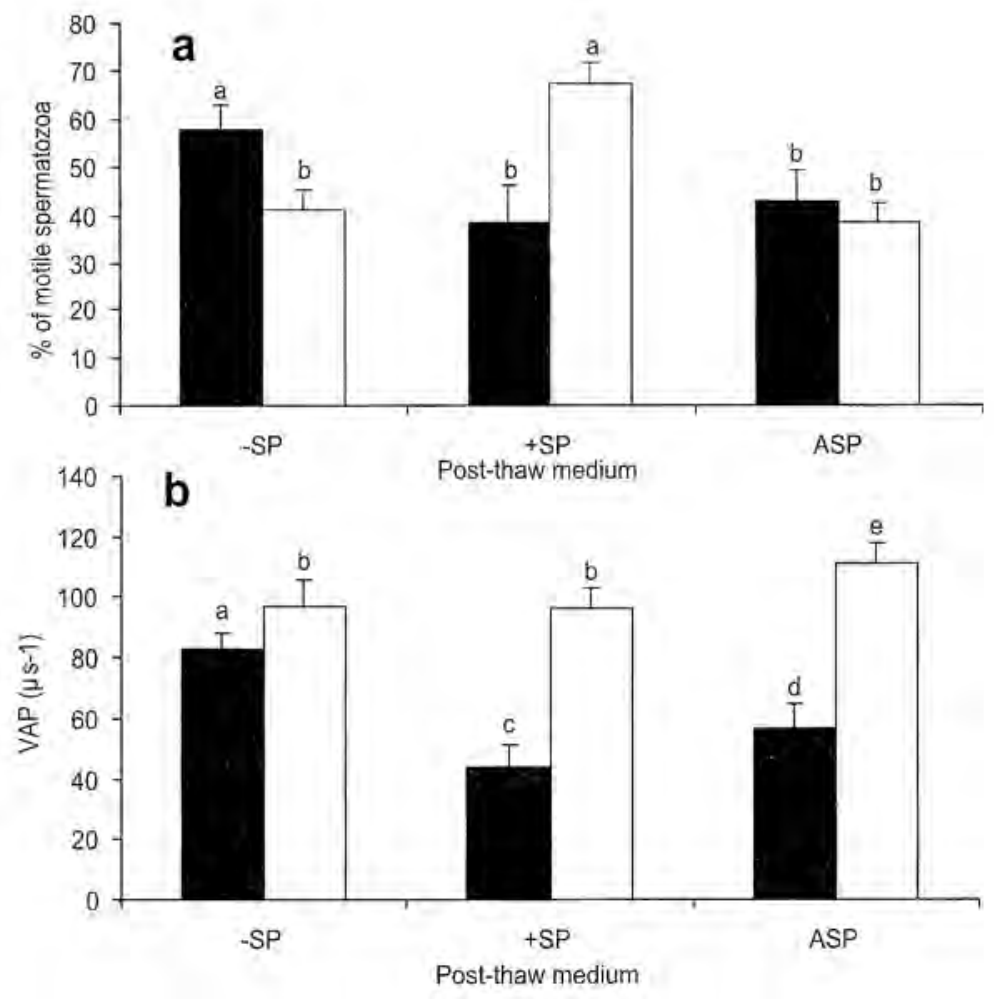

Fig, 5. The motility characteristics of [ $[$ ] unsorted or [ [ ] sex-sorted and frozen-thawed ram spermatozoa without (-SP) or with (+SP) whole or artificial seminal plasma (+ASP) in the post-thaw medium. Panel a: motility $(\%$, determined by CASA; HTM-IVOS; HamiltonThorne, USA) and panel $\mathbf{b}$ : average path velocity (VAP, $\mu \mathrm{ms}^{-1}$, determined by CASA). The post-thaw medium comprised Androhep (Minitube Australia, Smythes Creek, Australia) containing $0(-\mathrm{SP})$ or $20 \%(\mathrm{~V} / \mathrm{V})$ whole seminal plasma $(+\mathrm{SP})$ pooled from 6 rams or artificial seminal plasma (+ASP) as described by Mortimer and Maxwell (2000). Data are means \pm s.e.m. pooled for 0,3 and 6 hr post-thaw incubation at $37^{\circ} \mathrm{C}$. (S de Graaf, WMC Maxwell \& G Evans, unpublished observations).

removal of seminal plasma) but rather consecutive actions of positive and negative regulatory factors. These factors modulate the capacitation status of spermatozoa in a manner that varies with species, males within species, ejaculates within males, stage of sperm maturity and previous sperm treatment (Ashworth et al. 1994; Centurion et al. 2003; Bergeron et al. 2005). The addition of whole seminal plasma to spermatozoa may initially have simple influences associated with its ionic component, as suggested by the effects of ASP (Mortimer \& Maxwell 2004; and Fig. 5) but its subsequent action may be more complex. In the case of sex-sorted spermatozoa, the action of seminal plasma may depend on the proteins that remain on the sperm surface, after the dilution and mechanical agitation associated with the flow cytometric process, and their interaction with the particular factors present in the seminal plasma, or its fractions, added to them. 

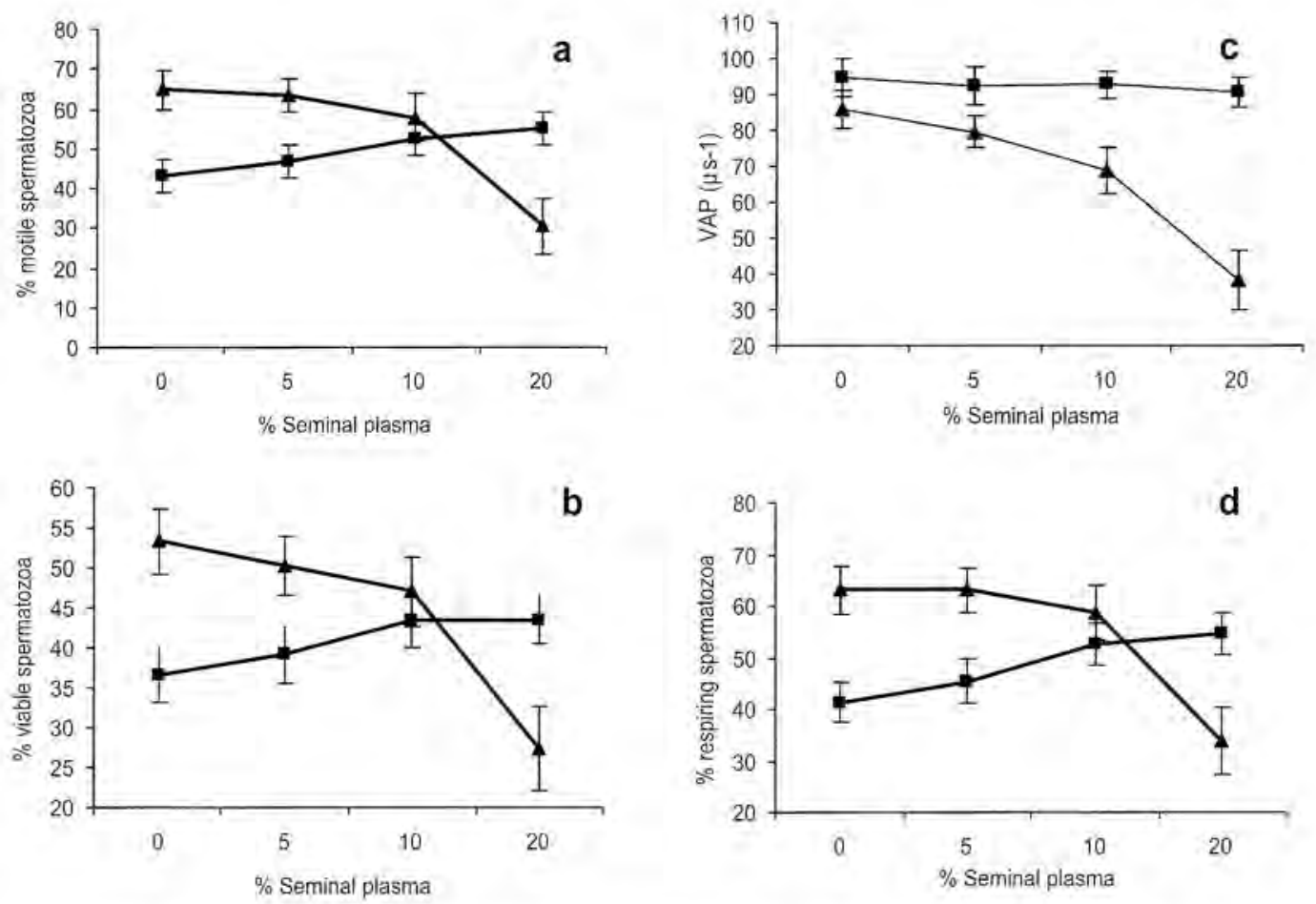

Fig. 6. The motility characteristics and mitochondrial activity of [-] unsorted or [ $\mathbf{\Lambda}]$ sexsorted and frozen-thawed ram spermatozoa without $(0 \%)$ or with $(5,10$ or $20 \%)$ seminal plasma in the post-thaw medium. Panel a: motility $(\%$, determined by CASA; HTM-IVOS; Hamilton-Thorne, USA), panel b: viability ( $\%$ live spermatozoa assessed by exclusion of ethidium homodimer-1), panel $c$ : average path velocity (VAP, $\mu m s^{-1}$, determined by CASA) and panel $\mathbf{d}$ : mitochondrial activity $(\%$ respiring spermatozoa, assessed by accumulation of R123 in the midpiece). The post-thaw medium comprised Androhep (Minitube Australià, Smythes Creek, Australia) containing $0,5,10$ or $20 \%(\mathrm{v} / \mathrm{v})$ whole seminal plasma pooled from 6 rams. Data are means \pm 5.e.m. pooled for 0,3 and 6 hr post-thaw incubation at $37^{\circ} \mathrm{C}$. (S de Graff, WMC Maxwell \& G Evans, unpublished observations).

\section{Conclusions}

Our studies have demonstrated both positive and negative effects of supplementary seminal plasma on the kinematics, membrane status and fertility of ram spermatozoa that have been subjected to preservation and/or flow cytometric sex sorting. The active components of seminal plasma responsible for these changes in sperm function are proteinaceous, of post-epididymal origin (most likely from the vesicular glands) and not associated with the membrane vesicle organelles in ram seminal plasma.

The major proteins that have been isolated and characterised in ram seminal plasma originate from the vesicular gland and comprise a $15.5 \mathrm{kDa}$ spermadhesin, together with four RSP proteins $(15,16,22$ and $24 \mathrm{kDa}$ ) with $\mathrm{Fn}-2$ domains (Bergeron et al. 2005) or RSVP-14 (homologous with RSP 15) and RSVP-20 (Fernández-Juan et al. 2006). The specific functions of these proteins are yet to be determined but the spermadhesin may have a role in stabilising sperm membranes (decapacitation) at ejaculation while the 15 (or RSVP-14) and $16 \mathrm{kDa}$ RSP proteins 
are more likely to be associated with binding and release to oviduct cells, capacitation and oocyte binding.

It is tempting to conclude that the active component of ram seminal plasma which provides protection to ram spermatozoa after freeze-thawing is the $15.5 \mathrm{kDa}$ spermadhesin which has been identified by Manjunath et al. (2002) as comprising the majority of ram seminal plasma protein, or RSVP-14 and RSVP-20 identified as more than half the ram seminal plasma protein by MuiñoBlanco, Cebrián-Pérez and co-workers (personal communication). However, there have been no investigations to date that provide conclusive evidence on the effects of individual seminal plasma proteins in any ruminant species, or even seminal plasma protein fractions, on the fertility of spermatozoa, whether fresh or preserved. It remains to be seen whether particular proteins, present in the seminal plasma of ruminants, could be characterised, synthesized and utilized as additives to sperm preservation media to improve fertility of females after Al.

\section{Acknowledgements}

The authors are grateful to XY Inc. (Fort Collins, CO), the Australian Research Council and the Geoffrey Gardiner Foundation of Victoria for financial support. Valuable research assistance and animal care has been provided by Roslyn Bathgate, Byron Biffin, Stephen Burgun, Lindsay Gillan, Kim Heasman, Tamara Leahy, Monica Ruckholdt, Andrew Souter, Keith Tribe and Shelley Underwood. We also thank Professors Detlef Rath, Teresa Muiña-Blanco, José Cebrián-Pérez and Juan-Maria Vázquez for their constructive comments on the manuscript.

\section{References}

Arienti G, Carlini E \& Palmerini CA 1997 Fusion of human sperm to prostasomes at acidic $\mathrm{pH}$. Journal of Membrane Biology 155 89.94.

Arienti G, Carlini E, de Cosmo AM, di Profio P \& Palmerini CA 1998 Prostasome-like particles in stallion semen. Biology of Reproduction 59 309-313.

Ashworth PJC, Harrison RAP, Miller NGA, Plummer JM \& Watson PH 1994 Survival of ram spermatozoa at high dilution: protective effect of simple constituents of culture media as compared with seminal plasma. Reproduction, Fentility and Development $\mathbf{6}$ 173-180.

Assreuy AM, Calvete JI, Alencar NM, Cavada BS, RochaFilho DR, Melo SC, Cunha FQ \& Ribeiro RA 2002 Spermadhesin PSP-1/PSP-II heterodimer and its isolated subunits induced neutrophil migration into the peritoneal cavity of rats. Biology of Reproduction 67 1796-1803.

Austin CR 1952 The capacitation of mammalian sperm. Nature 170326.

Barrios B, Pérez-Pé R, Gallego M, Tato A, Osada J, MuiñoBlanco T and Cebrián-Pérez JA 2000 Seminal plasma proteins revert the cold-shock damage on ram sperm membrane. Biology of Reproduction 63 1531-1537.

Barrios B, fernández-Juan M, Muiño-Blanco T \& CebriánPérez JA 2005 Immunocylochemical localization and biochemical characterization of two seminal plasma proteins that protect ram spermatozoa against cold shock, lournal of Andrology 26 539-549.
Bergeron A, Villemure M, Lazure C \& Manjunath P 2005 Isolation and characterization of the major proteins of ram seminal plasma. Molecular Reproduction and Development $71461-470$.

Beydoun H \& Saftlas AF 2005 Association of human leucocyte antigen sharing with recurrent spontaneous abortions. Tissue Antigens 65 123-135.

Boisvert M, Bergeron A, Lazure C \& Manjunath P 2004 Isolation and characterization of gelatin-binding bison seminal vesicle secretory proteins. Biology of Reproduction 70 656-661.

Brandon CI, Heusner GL, Caudle AB \& Fayrer-Hosken RA 1999 Two-dimensional polyacrylamide gel electrophoresis of equine seminal plasma protein 5 and their correlation with fertility. Theriogenology 52863 873.

Bravo PW, Skidmore JA \& Zhao XX 2000 Reproductive aspects and storage of semen in Camelidae. Animal Reproduction Science 62 173-193.

Breitbart H \& Rubinstein S 1982 Characterization of $\mathrm{Mg} 2+$-ATPase and Ca2 +-ATPase activity in membrane-vesicles from ejaculated ram seminal plasma. Archives of Andrology 9 147-157.

Brody I, Ronquist G \& Gottfries A 1983 Ultrastructural localization of the prostasome - an organelle in human seminal plasma. Uppsala Journal of Medical Sci. ences 88 63-80.

Brooks DE 1990 Biochemistry of the male accessory glands. In Marshall's Physiology of Reproduction, vol 
2, pp. 269-690. Eds GE Lamming and AS Parkes. Edinburgh, New York; Churchill Livingstone.

Buck L \& Axel R 1991 A novel multigene family may encode odorant receptors: a molecular basis for odor recognition. Cell 65 175-187.

Caballero I, Vazquez JM, Gil MA, Calvete IJ, Roca J, Sanz L, Parrilla I, Garcia EM, Rodriguez-Martinez H \& Martinez EA 2004a Does seminal plasma PSP-1/ PSP-II spermadhesin modulate the ability of boar spermatozoa to penetrate homologous oocytes in vitro? Journal of Andrology 25 1004-1012.

Caballero I, Vazquez IM, Centurión F, RodriguezMartinez H, Parrilla I, Roca J, Cuello C \& Martinez EA 2004b Comparative effects of autologous and homologous seminal plasma on the viability of largely extended boar spermatozoa. Reproduction in Domestic Animals $39370-375$.

Caballero I, Vazquez JM, Rodriguez-Martinez $\mathrm{H}$, Gill MA, Calvete J), Sanz L, Garcia EM, Roca J \& Martinez EA 2005 Influence of seminal plasma PSP-1/ PSP-II spermadhesin on pig gamete interaction. ZYgote 13 11-16.

Calvete JJ, Sanz L \& Töpfer-Petersen E 1994 Spermadhesins: structure-function relationships. Assisted Reproductive Technology/Andrology 6316 330.

Calvete J, Sanz L, Reinert M, Dostalova Z \& TöpferPetersen E 1995 Heparinbinding proteins on bull, boar, stallion and human spermatozoa. In Advances in spermatozoal phylogeny and taxonomy, pp 515-524. Eds BGM famieson, J Ausio \& H-L Justine. Paris: Mém. Mus. Natn, Hist. nat.

Calvete II, Raida M, Gentzel M, Urbanke, Sanz CL \& Töpfer-Petersen E 1997 Isolation and characterization of heparin-and phosphorylcholine-binding proteins of boar and stallion seminal plasma. Primary structure of porcine pB1. FEBS letters 407 201-206.

Cardozo IA, Fernández-Juan M, Forcada F, Abecia A, Muiño-Blanco T \& Cebrián-Pérez IA 2006 Monthly variations in ovine seminal plasma proteins analysed by two-dimensional polyacrlamide gel electrophoresis. Theriogenology, $66841-850$.

Carlini E, Palmerini CA, Cosmi EV \& Arienti G 1997 Fusion of sperm with prostasomes: Effects on membrane fluidity. Archives of Biochemistry \& Biophysics 343 6-12.

Carlsson L, Ronquist G, Nilsson BO \& Larsson A 2004 Dominant prostasome immunogens for sperm-agglutinating autoantibodies in infertile men. Journal of Andrology 25 699-705.

Castellini C, Lattaioli P, Moroni M \& Minelli A 2000 Effect of seminal plasma on the characteristics and fertility of rabbit spermatozoa. Animal Reproduction Science 63 275-282.

Catt SL, O'Brien JK, Maxwell WMC \& Evans G 1997 Assessment of ram and boar spermatozoa during cellsorting by flow cytometry. Reproduction in Damestic Animals 32 251-258.

Centurion F, Vazquez IM, Calvete IJ, Roca J, Sanz I, Parilla I, Garcia EM \& Martinez E 2003 Influence of porcine spermadhesins on the susceptibility of boar spermatozoa to high dilution. Biology of Reproduction 69 640-646.

Chang MC 1951 Fertilizing capacity of spermatozoa deposited into the fallopian tubes. Nature 168 597-698.

Chang MC 1957 A detrimental effect of seminal plasma on the fertilizing capacity of sperm. Nature 179258 259.

Cormier N \& Bailey IL 2003 A differential mechanism is involved during heparin- and cryopreservation-induced capacitation of bovine spermatozoa. Biology of Reproduction 69 177-185.

Cormier N, Sirard MA \& Bailey JL 1997 Premature capacitation of bovine spermatozoa is initiated by cryopreservation, Joumal of Andrology 18 461-468.

Corteel IM 1980 [Effects of seminal plasma on the survival and fertility of spermatozoa kept in vitro] [French]. Reproduction, Nutrition, Development 20 1111-1123.

Cross NL 1998 Role of cholesterol in sperm capacitation. Biology of Reproduction 59 7-11.

Cross NL 2003 Decrease in order of human sperm lipids during capacitation. Biology of Reproduction 69529 534.

Cummins JM \& Orgebin-Crist MC 1971 Investigations into fertility of epididymal spermatozoa. Biology of Reproduction 5 13-19.

Dacheux J-L \& Paquignon M 1980 Relations between the fertilizing ability, motility and maturation process in the boar. Annals New York Academy of Science $438526-529$.

Dacheux J-L, Gatti J-L \& Dacheux F. 2003 Contribution of epididymal secretory proteins for spermatozoa maturation. Microscopy Research Techniques 617 17.

de Cuneo MF, Vincenti LM, Martini AC, Ponce AA \& Ruiz RD 2004 Effects of PDC-109 on bovine sperm functional activity in presence or absence of heparin. Theriogenology 62 207-216.

de Graaf SP, Gillan L, Evans G, Maxwell WMC \& O'Brien JK 2004 The effecl of sheath fluid on the quality of sex-sorted ram spermatozoa. Reproduction, Fertility and Development 16 284-285.

Dostalova Z, Calvete II, Sanz L, Hettel C, Riedel D, Schoneck C, Einspanier R \& Töpfer-Petersen E 1994 Immunolocalization and quantitation of acidic seminal fluid prolein (aSFP) in ejaculated, swim-up, and capacitated bull spermatozoa. Biol Chem Hoppe Seyler 375 457-461.

Dukelow WR, Cheinoff HN \& Williams WL 1967 Properties of decapacitation factor and presence on various species. Journal of Reproduction and Fertility 14 393-399.

Eberhard WG 1996 Female control: sexual selection by cryptic female choice. Princeton University Press.

Ecroyd H, Sarradin P, Dacheux IL \& Gatti, IL 2004 Compartmentalization of prion isoforms within the reproductive tract of the ram. Biology of Reproduction 71 993-1001.

E-Haji Ghaoui R, Thompson PC, Evans G \& Maxwell WMC 2004 Characlerization and localization of membrane vesicles in ejaculate fractions from the ram. 
boar and stallion. Reproduction in Domestic Animals 39 173-180.

El-Hajj Ghaoui R, Thompson PC, Evans G \& Maxwell WMC 2006 The origin of membrane vesicles in ram seminal plasma. Reproduction in Domestic Anima/s 41 1-8.

Ericksson BM, Bathgate R, Maxwell WMC \& Evans G 2005 Effect of seminal plasma protein fractions on boar spermatozoa motility and acrosome integrity. Theriogenology 63 491. (Abstract)

Esch FS, Ling NC, Bohlen P, Ying SY \& Guillemin R 1983 Preliminary structure of PDC-109, a major protein constituent of bovine seminal plasma. Biochemical and Biophysical Research Communications 113 $861-867$.

Fabiani R, Johansson L, Lundkvist O \& Ronquist G 1994 Enhanced recruitment of motile spermatozoa by prostasome inclusion in swim-up medium. Human Reproduction 9 1485-1489.

Fernández-Juan M, Gallego $M$, Barrios B, Osada J, Cebrián-Pérez JA \& Muiño-Blanco T 2006 Immunohislochemical localization of sperm-preserving proleins in the ram reproductive tract. Journal of Andrology 27 588-595.

Foster RA, Ladds PW, Hoffmann D \& Husband AJ 1988 Immunoglobulins and immunoglobulin-containing cells in the reproductive tract of normal rams. Australian Veterinary Journal 65 16-20.

Fouchécourt S, Charpigny G, Reinaud P, Dumont P \& Dacheux J-L 2002 Mammalian lipocalin-type pro5taglandin D-2 synthase in the fluids of the male genital tract: putative biochemical and physiological funclions. Biology of Reproduction 66 458-467.

Fraser LR, Harrison RAP \& Herod IE 1990 Characterization of a decapacitation faclor associated with epididymal mouse spermatozoa. Journal of Reproduction \& Fertility 89 135-148.

Fraser LR, Adeoya-Osiguwa SA, Baxendale RW \& Gibbons R 2006 Regulation of mammalian sperm capacitation by endogenous molecules. Frontiers in Bioscience 11 1636-1645.

García-López N, Ollero M, Cebrián-Pérez IA \& MuiñoBlanco T 1996 Reversion of thermic-shock effect on ram spermatozoa by adsorption of seminal plasma proteins revealed by partition in aqueous two-phase systems. Journal of Chromatography B 680 137-143.

Garcia EM, Vázquez JM, Calvete JJ, Sanz L, Caballero I, Parilla I, Gil MA, Roca J \& Martínez EA 2006 Dissecting the protective effect of the seminal plasma spermadhesin PSP-1/PSP-11 on boar sperm functionality. Journal of Andrology 27 434-442.

Garner DL, Thomas, Gravance CG, Marshall CE, Dejarnette JM \& Allen CH 2001 Seminal plasma addition altenuates the dilution effect in bovine sperm. Theriogenology 56 31-40.

Gatti J-L, Druart X, Syntin P, Guerin Y, Dacheux J-L \& Dacheux F 2000 Biochemical characterization of two ram cauda epididymal maturation-dependent sperm glycoproteins. Biology of Reproduction 62 950-958.

Gatti J-L, Castella S, Dacheux F, Ecroyd H, Métayer S,
Thimon V \& Dacheux J-L 2004 Post-testicular sperm environment and fertility. Animal Reproduction Science 82-83 321-339.

Gatti J-I, Métayer S, Belghazi M, Dacheux F \& Dacheux J-L 2005 Identification, proteomic profiling, and origin of ram epididymal fluid exosome-like vesicles. Biology of Reproduction 72 1452-1465.

Gerena RL, Irikura D, Urade Y, Eguchi N, Chapman DA \& Killian, GJ 1998 Identification of a fertilityassociated protein in bull seminal plasma as lipocalintype prostaglandin D synthase. Biology of Reproduction 58 826-833.

Gibbons R, Adeoya-Osiguwa \& Fraser LR 2005 A mouse sperm decapacitation factor receptor is phosphatidyethanolamine-binding protein 1. Reproduction 130 497-508.

Gillan L \& Maxwell WMC 1999 The functional integrity and fate of cryopreserved ram spermatozoa: lournal of Reproduction \& Fertility Supplement 54 271-283.

Gillan L, Evans G \& Maxwell WMC 2000 The interaction of fresh and frozen-thawed ram spermatozoa with oviductal epithelial cells in vitro. Reproduction, Fertility Development 12 237-244.

Gillan L, Maxwell WMC \& Evans G 2004 Preservation and evaluation of semen for artificial insemination. Reproduction, Fertility Development 16 447-454.

Greube A, Müller K, Töpfer-Petersen E, Herrmann A \& Müller P 2004 Interaction of fibronectin type II proteins with membranes: The stallion seminal plasma protein SP-1/2. Biochemistry 43 464-472.

Green CE \& Watson PF 2001 Comparison of the capacitation-like state of cooled boar spermatozoa with true capacitation. Reproduction 122 889-898.

Gundogan M \& Elitok B 2004 Seasonal changes in re productive parameters and seminal plasma constituents of rams in Afyon province of Turkey. Deutsche Tierartliche Wochenschritt 111 158-61.

Guraya SS 2000 Cellular and molecular biology of $\mathrm{Ca}$ pacitation and acrosome reaction in spermatozoa. $\mathrm{In}$ ternational Review of Cytology 199 1-64.

Gwathmey T, Ignotz G \& Suarez S 2003 PDC-109 (BSP-A1/A2) promotes bull sperm binding to oviductal epithelium in vitro and may be involved in forming the oviductal sperm reservoir. Biology of Reproduction $69809-815$.

Henault MA \& Killian GJ 1996 Effect of homologous and heterologous seminal plasma on the fertilizing ability of ejaculated bull spermatozoa assessed by penetration of zona-free bovine oocytes. lournal of Reproduction \& Fertility 108 199-204.

Hoskins DD \& Vijayaraghavan S 1990 A new theory on the acquisition of sperm motility during epididymal transit. In Controls of sperm motility: Biological and clinical aspects, pp 53-62. Ed C Gagnon. Boca Raton: CRC press.

Huang Z \& Vijayaraghavan S 2004 Increased phosphorylation of a distinct subcellular pool of protein phosphatase, ppl\{gamma\}2, during epididymal sperm maturation. Biology of Reproduction 70 439-447.

Hunter RHF 1981 Sperm transport and reservoirs in the 
pig oviduct in relation to the time of ovulation. Journal of Reproduction \& Fertility 63 109-117.

Ibrahim NM, Gilbert GR, Loseth KJ \& Crabo BG 2000 Correlation between clusterin-positive spermatozoa determined by flow cytometry in bull semen and fertility. Journal of Andrology 21 887-894.

Jelinkova P, Lierda J, Manaskova P, Ryslava $\mathbf{H}$, Jonakova W \& Ticha M 2004 Mannan-binding proteins from boar seminal plasma. Journal of Reproductive Immunology 62 167-182.

Jobim MIM, Oberst ER, Salbego CG, Wald VB, Horn AP \& Mattos RC 2005 BSP A1/A2-like proteins in ram seminal plasma. Theriogenology $632053-2062$.

Johnson LA 2000 Sexing mammalian sperm for production of offspring: The state-of-the-art. Animal Reproduction Science 61 93-107.

Killian GJ, Chapman DA \& Rogowski LA 1993 Fertilityassociated proteins in Holstein bull seminal plasma. Biology of Reproduction 49 1202-1207.

Kraus M, Ticha M, Zelezna B, Peknicova I \& Jonakova V 2005 Characterization of human seminal plasma proteins homologous to boar AQN spermadhesins. Joutnal of Reproductive Immunology 65 33-46.

Kravets FG, Lee I, Singh B, Trocchia A, Pentyala SN \& Khan SA 2000 Prostasomes: Current concepts. Prostate 43 169-174.

Love CC, Brinsko SP, Rigby SL, Thompson JA, Blanchard TL \& Varner DD 2005 Relationship of seminal plasma level and extender to sperm motility and DNA integrity. Theriogenology 63 1584-1591.

Manjunath P \& Sairam MR 1987 Purification and biochemical characterization of three major acid proteins (BSP A1, BSP A2 and BSP A3) from bovine seminal plasma. Biochemistry 7 685-692.

Manjunath P \& Thérien I 2002 Role of seminal plasma phospholipids-binding proteins in sperm membrane lipid modification that occurs during capacitation. Journal of Reproductive Immunology 58 109-119.

Manjunath P, Sairam MR \& Uma J 1987 Purification of four gelatin-binding proteins from bovine seminal plasma by affinity chromatography. Biosciences Reports 7231.238.

Manjunath P, Nauc V, Bergeron A \& Ménard M 2002 Major proteins of bovine seminal plasma bind to the low-density lipoprotein fraction of hen's egg yolk. Biology of Reproduction 67 1250-1258.

Mann T 1954 The Biochemistry of Semen. London: Methuen and Co Lid.

Mann T 1964 The biochemistry of semen and of the male reproductive tract. London: Methuan and Co. LId.

Mann T \& Lutwak-Mann C 1981 Male reproductive function and semen. Themes and trends in physiology, biochemistry and andrology. Berlin: Springer-Verlag.

Maxwell WMC \& Hewitt L 1986 A comparison of vaginal, cervical and intrauterine insemination of sheep. Journal of Agricultural Science, Cambridge 106191. 193.

Maxwell WMC \& Johnson LA 1997a Chlortetracycline analysis of boar spermatozoa after incubation, flow cytometric sorting, cooling, or cryopreservation. Molecular Reproduction \& Development 46 408-418.
Maxwell WMC \& Johnson LA 1997b Membrane status of boar spermatozoa after cooling or cryopreservation. Theriogenology 48 209-219.

Maxwell WMC \& Johnson LA 1999 Physiology of spermatozoa at high dilution rates: The influence of seminal plasma. Theriogenology 52 1353-1362.

Maxwell WMC \& Watson PF 1996 Recent progress in the preservation of ram semen. Animal Reproduction Science 42 55-65.

Maxwell WMC, Welch GR \& Johnson LA 1997 Viability and membrane integrity of spermatozoa after dilution and flow cylometric sorting in the presence or absence of seminal plasma. Reproduction, Fertility \& Development 8 1165-1178.

Maxwell WMC, Long CR, Johnson LA, Dobrinsky IR \& Welch GR 1998 The relationship between membrane status and fertility of boar spermatozoa after flow cylometric sorting in the presence or absence of seminal plasma. Reproduction, Fertility \& Development $\mathbf{1 0}$ 433-440.

Maxwell WMC, Evans G, Mortimer ST, Gillan L, Gellatly ES \& McPhie CA 1999 Normal fertility after cervical insemination with frozen-thawed spermatozoa supple: mented with seminal plasma. Reproduction, Fertility \& Development 11 123-126.

Maxwell WMC, Evans G, Hollinshead FK, Bathgate R, de Graaf SP, Erikson B, Gillan L, Morton K \& O'Brien JK 2004 Integration of sperm sexing technology into the ART Ioolbox. Animal Reproduction 5cience 82-83 79. 95.

Mededovic S \& Fraser LR 2004 Angiotensin II stimulates CAMP production and protein tyrosine phosphorylation in mouse spermatozoa. Reproduction 127601 . 612.

Métayer S, Dacheux F, Guerin Y, Dacheux J-L \& Gatti J-L 2001 Physiological and enzymatic properties of the ram epididymal soluble form of germinal angiotensin I-converting enzyme. Biology of Reproduction 65 1332-1339.

Minelli A, Moroni M, Martinez E, Mezzasoma I \& Ronquist G 1998 Occurrence of prostasome-like membrane vesicles in equine seminal plasma lournal of Reproduction \& Fertility 114 237-243.

Minelli A, Allegrucci C, Mezzasoma I, Ronquist G, Lluis C \& Franco R $1999 \mathrm{Cd} 26$ and adenosine deaminase interaction: Its role in the fusion between horse membrane vesicles and spermatozoa. Biology of Reproduction 61 802-808.

Mokkapati S \& Dominic CI 1977 Morphology of the accessory reproductive glands of some male indian chiroplerans. Anatomischer Anzeiger 141 391-397.

Moore AI, Squires EL \& Graham JK 2005 Effect of seminal plasma on the cryopreservation of equine spermatozoa. Theriogenology 63 2372-2381.

Mortimer ST \& Maxwell WMC 2004 Effect of medium on the kinematics of frozen-thawed ram spermatozoa. Reproduction 127 285-291.

Moruzzi JF 1979 Selecting a mammalian species for the separation of $\mathrm{X}$ - and $\mathrm{Y}$-chromosome-bearing spermatozoa. Journal of Reproduction \& Fertility $57319-323$.

Moura AA 2005 Seminal plasma proteins and fertility 
indexes in the bull: The case for osteopontin. Animal Reproduction 2 3-10.

Moura AA, Chapman DA, Killian GJ \& Almquist JO 2005 Proteins in the accessory sex gland and cauda epididymis fluid as related to dairy bull fertility. Journal of Andrology 83 32. (Abstract)

Myles DG, Koppel DE \& Primakoff P 1990 Sperm surface domains and fertilization. In Fertilization in mammals, pp 169-177. Eds D Barry, JC Bavister and RSR Eduardo. Norwell Massacusetts: Serono Symposia.

Nagai T, Niwa K \& Iritani A 1984 Effect of sperm concentration during preincubation in a defined medium on fertilizalion in vitro of pig follicular oocytes. Journal of Reproduction \& Fertility 70 271-276.

O'Donnell JM 1969 Intracellular levels of sodium and potassium in bull spermatozoa in relation to cell metabolism. Journal of Reproduction \& Fertility $19207-$ 209.

Ollero M, Cebrián-Pérez JA \& Muiño-Blanco T 1997 Improvement of cryopreserved ram sperm heterogeneity and viability by addition of seminal plasma. Journal of Andrology $18732-739$.

Palmerini CA, Carlini E, Nicolucci A \& Arienti G 1999 Increase of human spermatozoa intracellular $\mathrm{Ca} 2+$ concentration after fusion with prostasomes. Cell Calcium 25 291-296.

Parks JE \& Ehrenwald E 1989 Cholesterol efflux from mammalian sperm and its potential role in capacitation, In Fertilization in mammals, pp 155-167. Eds D Barry, JC Bavister and RSR Eduardo. Norwell Massacusetts: Serono Symposia.

Parks JE \& Hammerstedt RH 1985 Developmenl changes occurring in the lipids of ram epididymal spermatozoa plasma membrane. Biology of Reproduction 32 653-668.

Paulen $x$ H, Soderquist L, Adnoy I, Nordstoga AB \& Berg KA 2005 Effect of vaginal and cervical deposition of semen on the fertility of sheep inseminated with frozen-thawed semen. Veterinary Record $156 \quad 372-375$.

Pérez-Pé R, Cebrián-Pérez JA \& Muiño-Blanco I 2001 a Semen plasma proteins prevent cold-shock membrane damage to ram spermatozoa. Theriogenology 56425 . 434.

Pérez-Pé R, Barrios B, Muiño-Blanco T \& Cebrián-Pérez JA 2001 b Seasonal differences in ram seminal plasma revealed by partition in an aqueous two-phase system. lowmal of Chromatography B $760713-121$.

Pérez-Pé R, Grasa P, Fernándéz-Juan $M$, Peleato $M L$, Cebrián-Pérez JA \& Muiño-Blanco T 2002 Seminal plasma proteins reduce protein tyrosine phosphorylation in the plasma membrane of cold-shocked ram spermatozoa. Molecular Reproduction and Development 61 226-233.

Pursel VG \& Johnson LA 1975 Freezing of boar spermatozoa: fertilizing capacity with concentrated semen and a new thawing procedure, Joumal of Animal $5 \mathrm{ct}$ ence 40 99-102.

Rath D \& Niemann H 1997 In vitro fertilization of porcine oocytes with fresh and frozen-thawed ejaculated or frozen-thawed epididymal semen obtained from identical boars. Theriogenology 47 785-793.
Reinert M, Calvete I, Sanz L, Mann K \& Topfer-Petersen E 1996 Primary struclure of stallion seminal plasma HSP7. a zona-pellucida-binding protein of the spermadhesin family. European fournal of Biochemistry 242 636-640.

Robaire B \& Hermo L 1988 Efferent ducts, epididymis, and vas deferens: Structure, function and their regulation. In The physiology of reproduction, vol 1, pp 999 1080. Eds E Knobil and ID Neill. New York: Raven Press.

Robertson SA 2005 Seminal plasma and male factor signalling in the female reproductive Iract. Cell Tissue Research 322 43-52.

Rodriguez-Martinez H, Larsson B, Pertoft H \& Kjellén L. 1998 GAGs and spermatozoon competence in vivo and in vitro. In Cametes: development and function, pp 239-274. Eds A Lauria, F Gandolfi, G Enne and I. Gianaroli. Italy: Serono Symposia.

Romăo MJ, Kölln I, Dias JM, Carvalho AL, Romero A, Varela PF, Sanz L, Töpfer-Petersen E \& Calvete JJ 1997 Crystal structure of acidic seminal fluid protein (aSFP) at $1.9 \AA$ resolution: a bovine polypeptide of the spermadhesin family. Journal of Molecular Biology 274 650-660.

Ronquist G, Brody I, Gottfries A \& Stegmayr B 1978a An $\mathrm{Mg} 2+$ and $\mathrm{Ca} 2+$-stimulated adenosine triphosphatase in human prostatic fluid. Part i. Andrologia 10 261272.

Ronquist G, Brody I, Gottfries A \& Stegmayr B 1978b An $\mathrm{Mg} 2+$ and $\mathrm{Ca} 2+$-stimulated adenosine triphosphatase in human prostatic fluid. Part ii. Andrologia 10427. 433.

Saalmann A, Münz S, Ellerbrock K, Ivell R \& Kirchhoff C 2001 Novel sperm-binding proteins of epididymal origin contain four fibronectin type II modules. Molecular Reproduction and Development 58 88-100.

Saez F, Frenette G \& Sullivan R 2003 Epididymosomes and prostasomes: their roles in post-testicular maturation of the sperm cells. Journal of Andrology 24149 154.

Salamon S \& Maxwell WMC 1995a Frozen storage of ram semen. 1. Processing, freezing, thawing and fertility after cervical insemination. Animal Reproduc tion Science 37 185-249.

Salamon S \& Maxwell WMC 1995b frozen storage of ram semen. II. Causes of low fertility after cervical insemination and methods of improvement. Animal Reproduction Science 38 1-55.

Smith JF, Parr J, Murray GR, McDonald RM \& Lee RDF 1999 Seasonal changes in the protein content and composition of ram seminal plasma. Proceedings New Zealand Sociery of Animal Production 59 223-225.

Spehr M, Gisselmann G, Poplawski A, Riffell JA, Wetzel CH, Zimmer RK \& Hatt H 2003 Identification of a testicular odorant receptor mediating human sperm chemotaxis. Science 299 2054-2058.

Suzuki-Toyota F, Itoh Y \& Naito K 2000 Reduction of intramembranous particles in the periacrosomal plasma membrane of boar spermatozoa during in vitro capacitation: A statistical study, Development Growth \& Differentiation 42 265-273. 
Swamy M) 2004 Interaction of bovine seminal plasma proteins with model membranes and sperm plasma membranes. Current Science 87 203-211.

Tedeschi G, Oungre E, Mortarino M, Negri A, Maffeo G \& Ronchi S 2000 Purification and primary structure of a new bovine spermadhesin. European Journal of Biochemistry 267 6175-6179.

Thérien I, Moreau R \& Manjunath P 1998 Major proteins of bovine seminal plasma and high-density lipoprotein induce cholesterol efflux from epididymal sperm. Biology of Reproduction 59 768-776.

Thérien I, Moreau R \& Manjunath P 1999 Bovine seminal plasma phospholipid-binding proteins stimulate phospholipids efflux from epididymal sperm. Biology of Reproduction 61 590-598.

Thérien I, Bousquet D \& Manjunath P 2001 Effect of seminal phospholipid-binding proteins and follicular fluid on bovine sperm capacitation. Biology of Reproduction 65 4 1-51.

Tollner TL, Yudin Al, Treece CA, Overstreet JW \& Cherr GN 2004 Macaque sperm release ESP13.2 and PSP94 during capacitation: The absence of ESP13.2 is linked to sperm-zona recognition and binding. Molecular Reproduction and Development 69 325-337.

Töpfer-Petersen E 1999 Carbohydrate-based interactions on the route of a spermatozoon to fertilization. Human Reproduction Update 5 314-329.

Töpfer-Petersen E, Romero A, Varela PF, Ekhlasi-Hundrieser M, Dostalova Z, Sanz L \& Calvete IJ 1998 Spermadhesins: A new protein family. Facts, hypothéses and perspectives. Andrologia 30 217-224.

Töpfer-Petersen E, Ekhlasi-Hundrieser M, Kirchoff C, Leeb T \& Sieme H 2005 The role of stallion seminal proteins in fertilisation. Animal Reproduction Science $\mathbf{8 9}$ 159-170.

Udby L, Lundwall A, Johnsen AH, Fernlund P, ValtonenAndre C, Blom AM, Lilja H, Borregaard N, Kjeldsen L \& Bjartell A 2005 Bela-microseminoprotein binds crisp3 in human seminal plasma. Biochenical \& Biopliysical Research Communications 333 555-561.

Vadnais ML, Kirkwood RN, Tempelman RJ, Sprecher DJ \& Chou K 2005 Effect of cooling and seminal plasma on the capacitation status of fresh boar sperm as deter- mined using chlortetracycline assay. Animal Repro. duction Science 87 121-132.

Vauquelin LN 1791 Expériences sur le sperme humain. Ann Chim 9, 64.

Varela PF, Romero A, Sanz L, Romão MJ, Töpfer-Petersen E \& Calvete J] 1997 The 2.4 A resolution crystal structure of boar seminal plasma PSP-1/PSP-II: a zona pellucida-binding glycoprotein heterodimer of the spermadhesin family built by a CUB domain architecture. Journal of Molecluar Biology 274 635-649.

Villemure M, Lazure C \& Manjunath P 2003 Isolation and characterization of gelatin-binding proteins from goat seminal plasma. Reproductive Biology \& Endocrinology 139.

Vittoria A, La Mura E, Cocca T \& Cecio A 1990 Serotonin, somatostatin-and chromogranin a-containing cells of the urethro-proslatic complex in the sheep. An immunocytochemical and immunofluorescent study. Journal of Anatomy 171 169-178.

Watson PF 1995 Recent developments and concepts in the cryopreservation of spermatozoa and the assessment of their post-thaw function. Reproduction, Fertitity \& Development 7 871-891.

Wedekind C, Chapuisat M, Macas E \& Rulicke T 1996 Non-random fertilization in mice correlates with the MHC and something else. Heredity 77 400-409.

Wolfe CA, James PS, Gunning AP, Ladha S, Christova Y \& Jones R 2001 Lipid dynamics in the plasma membrane of ram and bull spermatozoa after washing and exposure to macromolecules BSA and PVP. Moleculat Reproduction \& Development 59 306-313.

Yanagimachi R 1988 Mammalian fertilization. In The physjology of reproduction, pp 135-185. Eds E Knobil and ID Neill. New York: Raven Press.

Zhao XX 2000 Semen characteristics and artificial insemination in the Bactrian Camel. In Recent advances in Camelid reproduction. Eds JA Skidmore and GP Adams, International Veterinary Information Service (mmw,ivis.org).

Ziegler A, Kentenich H \& Uchanska-Ziegler B 2005 Female choice and the MHC. TRENDS in Immunology 26 496-502. 